New York University

Law and Economics Research Paper Series

Working Paper No. 04-009

\title{
Non-Management Director Options, Board Characteristics, and Future Firm Investments and Performance
}

\author{
Stephen Bryan \\ and \\ April Klein
}

This paper can be downloaded without charge from the Social Science Research Network Electronic Paper Collection at at

http://papers.ssrn.com/abstract $=550506$ 


\title{
Non-Management Director Options, Board Characteristics, and Future Firm Investments and Performance
}

\author{
Stephen Bryan* \\ and \\ April Klein** \\ May 2004 \\ * Stephen Bryan \\ Babcock Graduate School of Management \\ Wake Forest University \\ 7659 Reynolds Station \\ Winston Salem, North Carolina 27106 \\ 3367583671 \\ stephen.bryan@mba.wfu.edu \\ **April Klein \\ Stern School of Business \\ New York University \\ 44 West $4^{\text {th }}$ Street K-MEC 10-93 \\ New York, New York 10012 \\ aklein@stern.nyu.edu
}

We thank Daniel Collins, Fabrizio Ferri, Amar Gande, Lee-Seok Hwang, Donald Palmer, Peter Siegelman and David Yermack, and participants at the Fordham Law School corporate law seminar, the 2004 University of Texas Corporate Governance Conference, the $4^{\text {th }}$ annual Vanderbilt Law and Business Conference, and the European Business School for their helpful comments and suggestions. We gratefully acknowledge John Graham for data on marginal tax rates and Jennie Tucker, Vicki Mahu, and Krishna Agarwal for assistance on data collection. 


\section{Abstract \\ Non-Management Director Options, Board Characteristics, and Future Firm Investments and Performance}

This paper examines if non-management director pay packages are set in ways consistent with the optimal contracting theory. Under this theory, directors issue stock option grants as a means for providing non-management directors incentives to monitor adequately the risk-taking and investment opportunities that managers of the firm undertake. Our results are consistent with this theory. Using a sample of over 5200 observations between 1997 and 2002, we find that (1) agency costs differ substantially across our sample, (2) boards systematically set their compensation contracts to address these agency costs, and (3) significantly positive links exist between the ratio of current stock option grants-to-total compensation and seven future investment, risk and firm performance variables. The investment variables are next period's change in research and development expenditures and change in capital expenditures. The risk variable is next year's stock return volatility. The firm performance variables are next period's Tobin's Q ratio, return on assets (ROA), a market return on current investments, and this period's stock return. Our results are incremental to board characteristics, CEO stock option grants, and economic, firm-specific, yearly, and industry control factors. 


\section{Non-Management Director Options, Board Characteristics, and Future Firm Investments and Performance}

\section{Introduction}

The recent proliferation of corporate scandals has placed a spotlight on the role boards of directors play in monitoring publicly-traded firms. On the one hand, boards are criticized as being too passive and too captive of management. Proponents of this argument assert that boards are unwilling or unable to protect shareholders' interests from management's agency costs. ${ }^{1}$ An encapsulation of the ineffective board is Enron's board prior to the company's demise in 2001.

Despite this view, the U.S. Congress in enacting the Sarbanes-Oxley Act of 2002, and the stock exchanges in 2003, have turned to boards as a prime mechanism to deter financial reporting and other types of corporate scandals. Sarbanes-Oxley legislates the existence of board audit committees, giving them broad powers, rights, and responsibilities in financial reporting matters. The NYSE and the NASDAQ approved a series of governance listing requirements, including mandating all boards to have a majority of independent directors.

As a result of these recent legislative and regulatory reforms, many boards are reassessing their roles, responsibilities and best practices in achieving their goals. Admittedly, there are several ways boards can be structured to overcome agency problems between management and shareholders. This paper concentrates on the role non-management director

\footnotetext{
${ }^{1}$ This argument dates back to Berle and Means (1932), who present the case of the existence of agency problems between shareholders and upper management for large, corporations with diffuse ownership structures. More recently, Jensen (1993) and Lipton and Lorsch (1992) articulate the view of relatively inactive boards; Mace (1986) presents ample anecdotal evidence of how non-management directors shy away from challenging management in the boardroom; and Bebchuk et al. (2002) offer a series of reasons as to why directors are disinclined to challenge CEOs on executive compensation.
} 
pay packages play in aligning the interests of shareholders and managers. ${ }^{2}$ Specifically, we examine whether non-management director compensation packages are associated with mitigating debt and equity agency costs, and whether non-management director stock option grants result in firms investing more, taking on more equity risk, and having better firm performances for the years 1997 - 2002. Our analyses control for the effects of other board characteristics, e.g., board independence and board size, the CEO's compensation package, ownership structures, and other economic variables.

The use of stock option awards to motivate non-management directors is not free from controversy in academic and regulatory circles. Director pay packages are criticized as having too many (e.g., Fisch and Gentile, 2003) or too few stock options (e.g., Elson, 1996). Director pension plans are deemed as misalignments between directors' current duties and their pay schedules. The NYSE (2003) states that it does not consider stock ownership by a director to be a bar to independence. However, others allege that director pay is too inconsequential to have any tangible effects on how directors perform. To further stir the pot, directors, by and large, set their own pay packages, suggesting that directors themselves play a large role in creating agency costs between shareholders and themselves.

Consequently, we investigate two conflicting hypotheses. The first hypothesis is that director pay is set in accordance with the firm's debt and equity agency costs, and that it has tangible effects on the firm's investing decisions. This is an adaptation of the Jensen and Meckling (1976) pay-for-performance argument. It is also called the optimal contracting approach (e.g., see Bebchuk et. al, 2002). Under this hypothesis, stock options are seen as a means for providing non-management directors incentives to monitor adequately the risk-taking

${ }^{2}$ We define non-management directors as those directors who are not employed full-time and currently by the firm. Management directors include the CEO, President, CFO and other full-time workers. Non-management directors include outside directors and affiliated directors. 
and investment opportunities that managers of the firm undertake. The three connecting links behind the optimal contracting hypothesis are (1) agency costs differ substantially across firms, (2) boards systematically set their compensation contracts to address these agency costs, and (3) these contracts provide incentives to directors to monitor management's actions (see Smith and Stulz, 1985; Smith and Watts, 1992; and John and John, 1993). We examine each of these links as they relate to director pay.

There is evidence supporting the optimal contracting theory as it pertains to CEO compensation packages. Jensen and Murphy (1990) report a positive correlation between CEO stock options and firm performance. Guay (1999) finds a positive association between stockreturn volatility and the sensitivity of CEOs' wealth to equity risk. Bryan et al. (2000) find a positive relation between the mix of CEO stock option grants to cash compensation and equity agency costs, but a negative association between the mix of CEO restricted stock grants to cash compensation and these agency variables. Both Guay (1999) and Bryan et al. (2000) note that stock option grants have convex payoff functions, thus providing risk-averse CEOs incentives towards investing in risky, positive net-present-value projects.

The alternative hypothesis is that non-management director pay packages are either irrelevant to, or increase, agency costs between shareholders, creditors, and managers. Under this hypothesis, the associations between director stock option grants and agency costs, and between director stock option grants and managers' investment decisions are zero or even negative.

An argument for irrelevancy is that director pay is relatively minor, particularly for wealthy individuals. For example, between 1997 and 2002, average total director compensation, defined as retainer plus meeting fees plus the values of stock and option grants for the year, 
ranged between $\$ 81,930$ (1997) and $\$ 112,940$ (2000). Stock option grants over this period averaged $\$ 77,194$ per non-management director for firms that used options in their compensation packages. $^{3}$ A counter-argument is that non-management directors are rarely removed or voted off the board, and therefore, over the director's time horizon, total director compensation and stock option grants have greater wealth affects. As evidence, Vafeas (1999b) finds a significant increase in the share and option holdings of independent directors three years after their firms initially adopt a stock or options incentive plan. Yermack (2003) finds a significant increase in director wealth five years after being appointed to the firm, particularly if the firm performs well over time. This counter-argument, however, suggests that non-management directors may not be willing to "rattle the boat" so as to keep their current board seat or perhaps be asked to join other boards (Bebchuk et. al, 2002). If this is true, then there is no association between director stock option grants and managements' actions.

A negative association between director stock option grants and equity agency costs could occur if stock option grants are used for non-incentive purposes. For example, Core et al. (1999) find evidence in support of the view that CEOs are overcompensated and that boards of directors are compliant in providing CEOs with excess compensation. If directors set their compensation packages to mimic the CEO's package and if CEOs are overpaid, then a negative association could be found between director option awards and equity agency costs.

We use a three-step analysis on a sample of 6,976 firm-years over the 1997-2002 period to examine the linkages between non-management director pay, agency costs, and investment decisions. First, we demonstrate that agency costs vary substantially across firms included in our

\footnotetext{
${ }^{3}$ As we show in Table 1, the percent of firms issuing stock option grants range from 60.8 percent to 72.7 percent. Whereas the average option grant for firms issuing stock options is $\$ 77,194$, the average option grant for all firms (both issuing and non-issuing firms) is $\$ 52,022$. Neither of these averages is reported in Table 1.
} 
sample. Next, we test and find systematic associations between agency costs and the percentage of stock option grants contained in non-management director pay packages. ${ }^{4}$ Specifically, firms with greater investment opportunities, measured either as research and development expenditures (scaled by firm value) or market-to-book ratios (Smith and Watts, 1992; Gaver and Gaver, 1993), are more likely to give directors greater amounts of stock options than firms with more limited investment opportunities. Similarly, smaller firms, firms with less leverage in their capital structures, lower bankruptcy risks, and non-regulated firms are more likely to issue director stock options.

In this part of the analyses, we control for firm-specific economic attributes, board characteristics, CEO pay components, and ownership variables. Firms with lower liquidity, measured as free cash flows, are more likely to use stock option grants in their director pay packages. We also find that tax considerations are related to stock option awards in predictable ways.

We also examine the relation between director stock options and (1) whether the firm provides directors with pensions upon retirement and (2) CEO stock incentive plans. First, we report a negative association between director stock option grants and the existence of a nonmanagement director pension plan. We interpret this finding as further evidence in favor of the optimal contracting hypothesis. Second, we find that director stock option grants are positively related to CEO stock option grants. This result is not surprising and supports Bryan et al.'s (2000) findings that incentive contracts are constructed to mitigate equity agency issues. By adding both variables to our analysis, however, we control for omitted correlated variables. For

\footnotetext{
${ }^{4}$ Alternatively, we use stock option grants over cash compensation (fixed fee plus meeting fees) as our dependent variable (see Bryan et al., 2000). Our results are qualitatively the same with this variable, and thus we do not show the results in this paper.
} 
example, if directors set their pay packages to mimic the CEO's pay package, then we would get the same empirical results, but would come to a spurious conclusion that the results are related to director pay when in fact they are associated with CEO pay.

Although these findings are informative, they do not fully support the optimal contracting hypothesis. As Core et al. (1999) explain, there are many interpretations to our analyses, including model misspecification due to omitted correlated variables. More important, the analyses presented thus far do not answer the question as to whether director stock options are positively associated with managers investing in more risky, positive NPV investment opportunities.

To address this question, we use both OLS regression analyses and a two-stage least squared (2SLS) methodology in which we regress director stock option grants alongside other corporate governance, and control variables on six future investment and firm performance variables and current stock returns. We find significant positive relations between director stock option awards and changes in future capital expenditures, changes in research and development expenditures, and the future variability of stock returns. We also find positive associations between future return-on-assets (accounting profitability), Tobin's Q ratio, a market return on investment proposed by Jensen (1993), current stock returns and current director option awards. These findings lend further support to the optimal contracting theory in that they show tangible economic outcomes associated with director stock option grants. ${ }^{5}$ Our results are robust to whether we use OLS or a 2SLS method. In our analyses, we control for CEO stock options,

\footnotetext{
${ }^{5}$ As we later explain, a strict adherence to the optimal contracting theory would produce positive coefficients on the regressions of future investment and future variability variables, but zero coefficients for the firm performance regressions. The positive coefficient on stock option grants for the firm performance variables suggests that, in aggregate, firms are under-utilizing stock option grants. An alternative explanation is that our performance models are misspecified. However, as we also explain, a negative coefficient on stock option grants for the firm performance models would be consistent with firms investing in negative NPV projects, a finding inconsistent with the optimal contracting theory.
} 
time-series factors, and economic and corporate control variables . Thus, we conclude that directors, on average, issue non-management director stock option grants judiciously, and in a manner consistent with the optimal contracting theory.

We also replicate our analyses using non-management director restricted stock grants instead of stock option grants. A growing literature, e.g., Bryan et al. (2000), Feltham and Wu 2001), and Lambert and Larcker (2004), presents a case that restricted stock grants provide different investing incentives to managers than stock option grants. The difference is due to the disparity in payoff functions between the two - stock options are convex in stock price while stock is linear in stock price. These papers suggest that (1) restricted stock grants would be related differently to agency costs and future investment decisions vis-à-vis stock option grants and (2) stock option grants induce higher risk taking than restricted stock awards. Our empirical findings support both hypotheses.

Our paper contributes to the corporate governance literature in several ways. First, it provides empirical evidence to the growing literature (e.g., John and John, 1993; Guay, 1999; Bryan et al., 2000) that predicts how stock option grants can play a positive role in mitigating agency costs between managers and shareholders. Although previous studies examine this hypothesis for CEO stock option grants, we provide evidence that this argument holds for nonmanagement directors as well.

Second, our paper addresses the issue as to whether non-management director stock options have positive affects, or if they matter at all. The existing literature is sparse and divided on this issue. Perry (1999) finds that when directors of independent boards receive incentive compensation, the likelihood of CEO turnover following poor performance increases. He interprets this finding as proof positive that director stock options provide financial incentives for 
directors to monitor management. Brick et al. (2002), in contrast, conclude that directors are overpaid, and that the level of overpayment "may be associated with an environment of ineffective monitoring, which [they] term cronyism." In contrast, our study supports the view that non-management stock option grants play a positive role in mitigating an underinvesting agency problem.

Finally, our study may have some social implication in the current corporate governance environment. As a result of recent corporate failures, some firms are voluntarily changing their director pay practices. General Electric has eliminated options for directors, replacing them with “deferred stock units." Sara Lee, Nuevo Energy, and Starbucks have also reduced or eliminated the use of director options. Champion Enterprises is reducing its equity pay to non-management directors as well, citing political pressure (Lublin, 2003). The findings of this study suggest that firms need not "follow the pack," but should decide on equilibrium pay packages for their directors.

The remainder of the paper is structured as follows. Section 2 has a brief history of nonmanagement director compensation from the mid-1800s through the present. Section 3 describes the sample and presents data on various components of non-management director pay. In section 4, we present the hypotheses, methodology, and descriptive statistics for the tests surrounding the determinants of director stock option grants. The results are contained in section 5. Section 6 describes the hypotheses and methodology behind testing for the association between firm outcomes (future investment decisions, future firm performance) and the granting of nonmanagement director stock option grants. Sensitivity analyses on how our variables are defined and on using an OLS method are described in Section 7. Section 8 presents hypotheses and empirical results for our analyses on non-management restricted stock grants. Section 9 
summarizes our paper and offers conclusions about its relation to the corporate governance debate on director stock option grants.

\section{History of Non-Management Director Compensation}

Early corporate directors were the major shareholders of their firms and therefore did not receive additional compensation. Recognizing that directors' personal financial interests allowed them to reap the rewards of share price appreciation, coupled with the view that directors were not considered employees ("servants of the company"), courts maintained through the mid-1800s that directors not be compensated (Elson, 1996).

However, in the early 1900s, the size of corporations grew with economic expansion. Share ownership became more widespread and public corporations introduced the role of the professional manager. With these changes, boards expanded to include both shareholders and non-shareholders. Compensation for board members came to be considered necessary for the time spent fulfilling duties of the board, especially for those directors with little personal financial stake in the company. ${ }^{6}$ Remuneration was needed also to compensate directors for potential legal liability that could endanger their personal wealth. A reflection of these changes came in 1928 when the courts ruled that "exceptional or extraordinary" board service warranted compensation. By the mid 1940s, director compensation was common practice.

Over the ensuing years, compensation of boards of directors increased in size and complexity. In 1953, the Committee on Business Corporations of the American Bar Association authorized boards of directors to set their own compensation. Cash retainers, fees per meetings, pension plans, and non-cash forms of compensation (various insurance policies, e.g.) became

\footnotetext{
${ }^{6}$ Early forms of compensation consisted of a gold double eagle coin (worth about \$20) and "lucrative tips" (Elson, 1996).
} 
common, as well as consulting opportunities and equity-linked forms of pay. In 1969, the American Bar Association's Committee on Corporate Law issued the Model Business Corporation Act, which gave the board the authority to set the compensation of directors unless otherwise provided in the articles of incorporation. [also see Delaware General Corporation Code (DGCL) §141(h); New York Business Corporation Law (NYBCL) §713(e)]

Today, the laws and rules on how boards grant stock option awards to non-management directors are still evolving. Delaware gives the right to create director stock option plans exclusively to the board (DGCL $§ 157) .^{7}$ New York gives this right to the board (NYBCL $\S 202(13)$ ) but requires majority shareholder approval (NYBCL §505(d)). Further, in 2003, NASDAQ amended its listing requirements by mandating shareholder approval for the establishment of a stock option plan for officers or directors [NASDAQ Marketplace Rule Sec. 4310(c)(25)(i)(a)]. Thus, the exchanges are supplementing state law in determining how boards set their compensation packages. ${ }^{8}$

Outside factors often influence how directors set their pay packages. In 1995, a report by the National Association of Corporate Directors' Commission on Director Compensation, (the Commission) made a series of recommendations designed to improve corporate governance through non-management director pay. Among these recommendations, the Commission called upon companies to pay their directors primarily in equities, set substantial stock ownership

\footnotetext{
${ }^{7}$ Shareholders can sue directors for wasting corporate assets if they feel that directors are being overcompensated. However, a shareholder vote approving, for example, the issuance of stock options to board members shifts the burden of proof from the board to the shareholders. For this reason, many companies present director option plans directly to the shareholder.

${ }^{8}$ Although federal law has not yet replaced state law governing shareholder-director relationships, federal law does supplement state law through explicit disclosure requirements that are designed to increase the protection of shareholders (Thompson, 1999).
} 
targets for directors, and abolish non-management pension plans. The stated goal of these recommendations is to align more closely director and shareholder interests. Following this report, the Investor Rights Association of America (IRAA) proposed over 120 shareholder resolutions calling for non-management director equity-based compensation as well as the abolishment of director pension plans (Elson, 1996). As Elson (1996) reports, in 1996, many companies adopted the IRAA's recommendations in exchange for its withdrawal of the actual proposals. $^{9}$

As we later demonstrate, the report appears to have had a major influence on how nonmanagement pay packages were set. We find a substantial increase over time in the percentage of firms in our sample using stock option grants as part of the non-management director pay mix and a very steady and large increase in the percentage of firms discontinuing their nonmanagement director pension plans. Thus, our paper has direct implications on the ramifications of the Commission's recommendations for non-management director pay incentives.

\section{Sample and non-management director pay descriptive statistics}

\subsection{Sample}

We test our hypotheses on a sample of 6,976 observations over a six-year period for 2,267 publicly-traded U.S. firms. The data on non-management director compensation are taken from Standard \& Poor's (S\&P) ExecuComp database for the 1997-2002 period. Firms changing their fiscal year-ends are dropped (for that particular year) to ensure that director compensation relates to the whole year. The sample firms must also have data on the determinants and on the parameters of the Black-Scholes option pricing model available from Compustat and CRSP

\footnotetext{
${ }^{9}$ These companies include American Express, Archer-Daniels-Midland, Bell Atlantic, Campbell Soup, Chrysler, Digital Equipment, ITT, McGraw Hill, NationsBank, Texas Instruments, and Woolworth.
} 
databases. The data on institutional stock ownership are from Compact Disclosure and from Thomson Financial. We obtain data on board characteristics from the Investor Responsibility Research Center.

\subsection{Descriptive Statistics}

\subsubsection{Descriptive statistics for director compensation by year}

Non-management director compensation consists of cash compensation, stock option awards, stock grants, and pension plans, which represent a form of deferred compensation. Cash compensation is defined as the annual cash retainer plus the number of board meetings times the fee per meeting. We measure the dollar value of stock option grants as per share option value times the number of options awarded. We use the Black-Scholes (1973) model to derive an exante per share option value. ${ }^{10}$ Stock compensation is the number of shares granted times the average stock price for the year. We also use an indicator variable as our measure of a nonmanagement director pension plan. We define the "mix" of director stock options to total compensation as the dollar amount of stock option grants divided by the sum of dollar amounts of total cash compensation, stock compensation, and stock option grants.

Table 1, Panel A gives the time series averages and proportions for our sample. The average annual retainer steadily grows from $\$ 19,278$ in 1997 to $\$ 23,172$ in 2002 . The average fee per meeting hovers slightly above $\$ 1,000$ for the sample period, from a low of $\$ 1,046$ in 1997 to a high of $\$ 1,129$ in 2002 . The average number of meetings per year clusters around

\footnotetext{
${ }^{10}$ See Appendix for a detailed description. The value contains measurement error to the extent that Black-Scholes does not incorporate unique characteristics of stock options, such as non-transferability of stock options and directors' limited ability to hedge their wealth (Huddart, 1994; Cuny and Jorion, 1995; Carpenter, 1998, Hall and Murphy, 2002). The metric also does not include one-time stock options that are often granted to non-management directors upon their nomination. If this one-time option grant reduces the need for further annual option grants, then our measure understates the incentive effects derived from stock options.
} 
seven. Total cash compensation ranges from $\$ 26,654$ in 1997 to a high of $\$ 31,137$ in 2002, a 17 percent increase over six years.

In comparison, non-management director stock option grants accrete at a swifter pace over the sample period, both in the number of equity instruments awarded and in dollar value. The average value of stock option grants grows from $\$ 41,518$ in 1997 to $\$ 69,386$ in 2000 , an increase of 67 percent, and then declines to $\$ 55,335$ in $2002 .{ }^{11}$ Even with this decline, there is a 33 percent increase dollar value over the 1997-2002 period. The yearly changes in option values mirror the rise and fall of the stock markets throughout the time period.

In contrast, the average value of the stock grants grows from $\$ 13,733$ to $\$ 16,504$, a $20 \%$ increase from 1996 to 2002. Total compensation increases by a factor of over one-third (from $\$ 81,930$ in 1997 to $\$ 112,940$ in 2000 ), reflecting the tremendous growth in stock option compensation, but falls to $\$ 102,976$ commensurate with the decline in equity markets. The greatest one-year change in total compensation occurs from 1998 to 1999, driven mainly by the jump in the average value of the stock option awards. In 1998, the average option award was $\$ 43,184$, rising to $\$ 60,192$ in 1999 , a 39 percent increase.

Not only has the average dollar amount of stock option compensation grown between 1997 and 2002, but the proportion of firms using stock option grants as a component of nonmanagement director has also risen. The proportion of firms issuing option awards (\%Option Firms) is 72.7 percent in 2002, up from 60.8 percent in 1997 . Interestingly, the proportion of firms issuing stock grants (\%Stock Firms) remains relatively flat over this period, ranging from 35.8 percent in 2001 to 39.2 percent in 1998. Conversely, the proportion of firms covering directors under a pension plan (\%Pension Firms) has fallen significantly, from 17.7 percent in

\footnotetext{
${ }^{11}$ These numbers, though quite large, do not approach the average Black-Scholes options value for CEOs and other top managers. Thus, the non-diversification effects of option pricing for non-diversified, risk-averse managers is mitigated for non-management directors.
} 
1997 to only 4.6 percent in 2002 . One proposed reason for the decline in retirement plans is that they are not performance based (Oppermann, 1997). Elson (1996) argues against pension plans because they reward board longevity, a factor highly influenced by management, and not the quality of the directors' service on the board.

Because our data begin in 1997, we cannot comment directly on the immediate effects of the NACD Commission's 1995 report that recommended that firms use equity-based pay for non-management directors and discontinue director pension plans. However, using the ExecuComp database, we find that in 1995, 47.8 percent of firms issued non-management director option grants, 20.6 percent of the sample issued stock grants, and 34.2 percent of firms had director pension plans in place. In contrast, in 1997, 60.8 percent of firms used option awards, 36.9 percent used stock grants, and only 17.7 percent had pension plans in place. Thus, in the two years since the issuance of the report and the beginning of our sample, we document relatively large increases in equity-based compensation, and the beginning of the dismantling of non-management director pension plans.

\subsubsection{Descriptive statistics for director compensation by industry}

Panel B of Table 1 presents director compensation components across industries. There are extensive variations in non-management director pay packages across industries. Utilities (Utility) and transportation (Trans) firms have the lowest levels of total director compensation, whereas communication (Comm) and service (Serv) firms pay the highest. The low level of compensation for the utility industry is consistent with its (partial) regulatory status. ${ }^{12}$ Although the National Energy Policy Act of 1992 deregulated segments of the utility industry, the Federal

\footnotetext{
${ }^{12}$ It is also consistent with the executive compensation literature that shows that CEOs of utilities are paid less than CEOs in other industries (Joskow et al., 1996).
} 
Energy Regulatory Commission continues to oversee the transmission of electric power, and state public utility commissions have jurisdiction over the retail of electricity (Bryan and Hwang, 1997).

There are also marked variations across industries in the use of stock option grants for non-management directors. The percentage of firms per industry including stock option grants as a component varies from one-third or less for petroleum (Petrol) firms and utilities to over seventy percent for manufacturing and mining (MM) and service firms. ${ }^{13}$ Conversely, utilities have the highest proportion of firms issuing stock grants (71.4 percent), and service firms have the lowest proportion (23.0 percent). As for pension plans, 22.2 percent of petroleum firms and 22.1 percent of utilities provide pension for non-management directors against only 3.7 percent and 4.1 percent, for service and retail firms, respectively.

These variations in director pay components support the view that there are fundamental driving forces behind determinants of pay packages. We address this issue by examining the association between firm-specific factors, e.g., equity agency costs and economic determinants, and director stock option grants. We also include industry dummy variables in our empirical analyses to capture industry-specific effects not specified by our independent variables.

\section{Hypotheses and Methodological Issues: Determinants of director stock option grants}

Our basic equation to analyze the determinants behind director stock option grants is:

Director Stock Option Grants G $_{i}=f\left(f_{i r m}\right.$ agency costs $_{i}$, economic variables , $_{\text {, }}$ bard characteristics, $_{i}$, CEO pay components, equity ownership cond $_{i}$ and or controls $\left.s_{i}\right)$

\footnotetext{
${ }^{13}$ In a similar vein, the average dollar value of stock option grants varies from $\$ 9,668$ for petroleum companies to $\$ 101,945$ for service firms.
} 
Director stock option grants is the mix of the dollar values of non-management stock option grants divided by total non-management compensation. Since many firms (approximately 30 percent) do not grant stock options, we use a Tobit model to derive and evaluate our empirical results. The Tobit model allows for the dependent variable to be zero or positive. Under this approach, the dependent variable (director stock option grants) is equated to a linear combination of explanatory variables with unknown coefficients plus a normally distributed disturbance, provided that this number is positive; otherwise the dependent variable takes the zero value (Theil, 1971). The Tobit model uses a maximum-likelihood method to estimate the unknown coefficients. We report the Tobit regression results using panel data in order to utilize all available information relating to year-to-year variation. However, the cross sectional and time series data in the panel data set could exhibit both heteroscedasticity and serial correlation. Therefore, we calculate robust standard errors and t-statistics, consistent with Yermack (1995).

\subsection{Agency costs}

Agency costs include possible valuation losses to shareholders or creditors due to misalignments of incentives between stakeholder and management, and between shareholders and creditors. Under the optimal contracting theory, we hypothesize a positive relation between non-management director stock option awards and equity agency costs. This is due to the fact that shareholders want to maximize their equity value by having managers undertake all positive, NPV projects, regardless of the risk levels. In contrast, debtholders want the firm to provide them with a steady stream of cash interest payments and, ultimately, their repaid principals. This suggests a negative relation between non-management director stock option awards and debt agency costs. We use the following variables as proxies for equity and debt agency costs. 


\subsubsection{Investments Opportunities}

The greater and more risky the immediate investment opportunity set is to the firm, the higher the equity agency costs are to the firm. A company with a rich set of investment opportunities has greater informational asymmetries that increase the likelihood of opportunistic behavior by managers (Lewellen et al., 1987; Clinch, 1991; Smith and Watts, 1992; Bizjak et al., 1993; Gaver and Gaver, 1993; Yermack, 1995; Bushman et al., 1996; Kole, 1997; Bryan et al., 2000). Further, risk-averse managers require incentive or monitoring arrangements that induce risk-taking decisions (John and John, 1993; Guay, 1999; Bryan et al., 2000).

Since stock-based compensation captures future as well as present cash flows, it has been proposed that it dominates cash as a form of compensation for managers of investment-rich firms (Smith and Watts, 1992; Elson, 1996). However, there are two types of stock-based compensation, stock option grants and stock grants. The NACD Commission Report (1995) and Elson (1996) argue that there is little difference between the mechanics of equity pay and that preferences towards options or stock grants appear to be "purely taxation driven" (Elson, 1996). However, as Guay (1999) and Bryan et al. (2000) demonstrate, the incentives attached to stock option awards are not equivalent to stock grants. Stock option awards provide a convex payoff schedule, which more likely induces the risk-taking that is critical for high investment opportunity firms. By comparison, stock grants, because of their linear payoff schedule, may contribute to the under-investment problem (Smith and Stulz, 1985) as board members forego risky, yet value-increasing, projects. Thus, we predict that high investment opportunity firms will use stock option awards more heavily than stock grants in non-management directors' compensation packages. 
To measure investment opportunities, we use the market-to-book ratio and, alternatively, research and development expenditures scaled by the market value of the firm, consistent with prior studies (e.g., Gaver and Gaver, 1993; Baber, Janakiraman, and Kang, 1996).

\subsubsection{Firm leverage}

The greater the leverage, the greater the agency cost of debt, defined as the severity of the conflict between creditors and stockholders. Debtholders want a steady stream of cash flows to ensure timely payments of interest and principal resulting in less risky investments, leading to an underinvestment problem. Further, debtholders demand premiums for increased firm risk, which can occur if incentive plans attempt to align the interests of managers, directors, and stockholders at the expense of debtholders (John and John, 1993; Yermack, 1995). If, as Grossman and Hart (1982), Jensen (1986) and Stulz (1990) assert, debtholders play a disciplinary role in the corporate governance structure by limiting overinvestment, then we predict an inverse relation between leverage and the use of stock options awards in director compensation packages. We measure leverage as the sum of short-term and long-term debt scaled by the book value of total assets.

\subsubsection{Financial Distress}

As firm performance declines relative to expectations, debt agency problems increase. In acute situations, such as financial distress, bondholder-stockholder conflicts intensify due to information problems faced by the distressed firm's claimholders on how to obtain unbiased information about the firm's future cash flow uncertainties (Wruck, 1990). Gilson (1990) presents evidence that creditors assume greater control over the firm and its investing decisions 
after a firm declares bankruptcy or has a debt restructuring. For example, he examines a sample of fifty firms that privately restructured their debt to avoid bankruptcy between 1979 and 1985 . For this sample, 30.0 percent of the restructured debt agreements include a general restriction on the level of capital expenditures as a restrictive covenant, and 22.5 percent include a restriction on permitted kinds of investments. Gilson and Vetsuypens (1993) show that the average firm grants relatively few options to CEOs in the six years prior to a firm declaring bankruptcy or undergoing a debt restructuring. They also present evidence consistent with the interpretation that the same pattern holds for independent director stock options - that is, few firms have director stock option plans prior to suffering financial distress. We measure financial distress as Altman's (1993) Z-score. Since a higher Z-score implies greater financial health, we posit a positive relation between Altman's Z and the use of director stock option grants.

\subsubsection{Regulated Industries}

Direct monitoring and oversight by regulatory authorities decrease information asymmetries in regulated industries, thereby decreasing the monitoring activities required by boards of directors (Demsetz and Lehn, 1985; Smith and Watts, 1992). Utilities are overseen partially by the Federal Energy Regulatory Commission and state commissions. Consequently they invest in relatively low risk, low beta investments, rarely seeking other investment avenues. $^{14}$ We include a dummy variable equal to one if the firm is a utility, and zero otherwise. We predict a negative association between the indicator variable, Utility, and the use of director option grants.

\footnotetext{
${ }^{14}$ The one noted exception during our time period is Enron, which became a futures trading house, and subsequently filed for bankruptcy in 2001. The National Energy Policy Act of 1992 allowed firms more freedom to invest in unregulated, nonutility businesses. Some firms chose to do than, Enron being a case in point. However, not all firms pursued that avenue and furthermore part of utility operations remains regulated.
} 


\subsubsection{Firm Size}

The direction of the association between firm size and the non-management director stock option awards is ambiguous. On one hand, equity agency costs increase with firm size because a larger span of operation allows for greater managerial opportunism and an increased need for effective external monitoring (Jensen and Meckling, 1976; Eaton and Rosen, 1983). In contrast, as firms grow, they invest resources to establish effective internal control mechanisms, accounting systems, budgeting processes, and performance evaluation systems. If such planning and control systems provide timely information to the board on managerial performance, then the demand for incentive sensitive board compensation is likely to be reduced.

We use the natural logarithm of total assets as a proxy for firm size. We make no a priori prediction on the association between firm size and director stock option grants.

\subsection{Economic Determinants}

\subsubsection{Free Cash Flow}

Firms with low liquidity are more likely to use stock-based compensation for their CEOs rather than cash compensation, since stock-based compensation conserves cash (Bryan et al., 2000). In addition, firms with low liquidity are more likely to have high growth opportunities (Fama and French, 2001), suggesting an inverse relation between cash flows and equity agency costs. ${ }^{15}$ We measure liquidity as free cash flows, which we measure as operating income before depreciation less the sum of income tax, interest and dividends scaled by market value of the

\footnotetext{
${ }^{15}$ In support of this assertion, we find significantly negative correlations between our liquidity measure (free cash flows) and our two measures of investment opportunities (market-to-book ratio and R\&D expenditures). See Table 3 for the correlations and significance levels.
} 
firm. ${ }^{16}$ Under the liquidity constraint argument, we predict a negative relation between nonmanagement director option awards and free cash flows.

On the other hand, Jensen (1986) articulates that firms with high free cash flows are more likely to over-invest in negative NPV projects. Under this scenario, high free cash flow firms face higher agency costs, suggesting that non-management directors would mitigate the overinvestment problem by granting themselves more stock options. Thus, the alternative hypothesis is a positive relation between non-management director option grants and free cash flows.

\subsubsection{Tax costs}

Stock option awards provide either no tax deduction for "incentive" stock options or a tax deduction that is deferred until the options are exercised for "non-qualified" stock options. Cash compensation, by contrast, is immediately deductible. Therefore, the opportunity costs of losing the tax benefits by using stock option awards increase with firms' marginal tax rates (Scholes and Wolfson, 1992; Matsunaga, 1995). Consequently, we expect firms with high marginal tax rates to shift the mix of director pay away from stock options and toward cash compensation. Using simulated marginal tax rates, we predict a negative association between the marginal tax rate and the use of stock option grants. ${ }^{17}$

\subsection{Board of Director Characteristics}

We include four board characteristics. Following Fama and Jensen (1983) and Klein (1998), we distinguish between two overall board functions - advising the CEO on investment opportunities and monitoring the CEO's actions. Both functions are vital to the corporation.

\footnotetext{
${ }^{16}$ We alternatively define free cash flows as cash flows from operating activities less cash outflows for investing activities, scaled by firm value, a measure consistent with Matsunaga (1995) and Dechow, et al. (1996), and we obtain qualitatively similar results. Section 7.2 contains the empirical results with this measure.

${ }^{17}$ We thank John Graham for providing us with this data.
} 
Monitoring encompasses the dissemination of unbiased information to investors (Klein, 2002), measurement of the CEO's performance, and the implementation of rewards to the CEO (Fama and Jensen, 1983). To be an effective monitor, directors need to be independent of management's influences, and often rely on outside counsel, for example, external auditors and compensation experts. On the other hand, the advisory role suggests that directors require access to firm-specific information and have the time and energy to evaluate and implement new investments.

Under the optimal contracting theory, director stock option grants mitigate the problem of underinvestment in risky, positive NPV projects. Accordingly, we hypothesize that boards strongly involved in an investment advisory role are more apt to use director stock option grants since these boards are more active in working with the CEO in initiating, evaluating, and implementing long-run investment decisions. While it is not possible to discriminate between "advisory" and "monitoring" functions, per se, there is a body of literature suggesting certain board characteristics are closely aligned to the investment advisory function. We include these board characteristics in our model and predict a positive association between the amount of director stock option grants and the following board variables.

\subsubsection{Inside Directors}

Inside directors (e.g., firm employees) provide firm-specific expertise, and by definition, are unable to monitor the CEO. Non-management directors provide both functions, with independent directors taking on the lion share of monitoring responsibilities. Several recent studies show that independent directors are effective monitors of the financial accounting process (Carcello and Neal, 2000, 2003; Klein, 2002) and CEO compensation (Core et al., 1999). In 
contrast, no study has produced convincing evidence showing that board independence enhances firm performance. Bhagat and Black (2002) find no correlation between the two and Agrawal and Knoeber (1996) and Klein (1998) find negative associations between the percentage of independent directors on the board and firm performance. These findings suggest that more independent boards may provide effective external monitoring, but do not add firm value in their investment advisory roles. Conversely, inside directors, given their superior knowledge of the firm and their employment relationship with the firm, may be in a better position to fill investment advisory roles. Klein (1998) supports this view by finding positive associations between the percentage of inside directors on board investment and finance committees and firm performance.

We define an inside director as one that is also an employee of the firm. We predict a positive relation between director stock options grants and the percent of inside directors on the firm's board.

\subsubsection{Board Size}

Large boards encounter more severe problems involving communication, coordination, and decision-making (Jensen, 1993; Lipton and Lorsch, 1992; and Eisenberg et al., 1998). Studies show an inverse relation between board size and monitoring, and between board size and firm performance. Beasley (1996) documents a positive association between board size and likelihood of financial fraud. Core et al. (1999) shows a positive association between CEO compensation and board size. Both are examples of board size hindering the monitoring function. 
On the other hand, Yermack (1996) finds an inverse relation between Tobin's Q ratio, a measure of firm performance, and board size. His results suggest that larger boards are less able to provide effective oversight into the investment advisory function. We hypothesize a negative relation between director stock option grants and board size.

\subsubsection{Director Age}

We create an indicator variable for each director) equal to one if the director is at least 62 years old, and zero otherwise. We then calculate the percentage of directors who are over this age. Core et al. (1999) present evidence that older independent directors do not monitor as effectively as their younger counter-parts. We propose that older directors - management and non-management directors - do not administer their advisory roles as well as younger directors. We choose 62 as our cut-off age because that is when U.S. citizens become eligible for social security. We posit that perhaps as directors contemplate retirement, they limit their long-term horizons as it pertains to advising management on long-run investment strategies. We predict a negative association between stock option grants and the percent of non-management directors who are 62 years of age or older.

\subsubsection{CEO Duality}

CEO Duality is when the firm's CEO also serves as the chairman of the board. The relation between CEO duality and director stock option grants is not clear. Fama and Jensen (1983), Lipton and Lorsch (1992) and Jensen (1993) argue that CEO duality is an impediment to effective monitoring by the board since it violates the principle of separation of decision making from control. Evidence in favor of this view is presented by Goyal and Park (2002) who show 
that CEO duality hinders the board's flexibility in replacing poorly-performing CEOs and Core et al. (1999) who find a positive association between excessive CEO compensation and CEO duality. On the other hand, Brickley et al. (1997) and Baliga et al. (1996) find no evidence that separating or combining the two positions affects firm performance in any discernible way.

Perhaps the most germane observation about CEO duality is that in the United States, it is the norm and not the exception. Previous studies document that 68 percent to 84 percent of U.S. boards for publicly-traded firms vest the same individual with both titles (Core et al., 1999; Vafeas, 1999a; Faleye, 2003). Two papers posit possible reasons behind this phenomenon. Brickley et al. (1997) argue that there are costs in separation, and that firms will split the two positions only when the firm's agency costs are high. Under this scenario, we expect a negative relation between CEO duality and director stock options under the assumption that stock options are granted in direct proportion to agency costs.

Hermalin and Weisbach (1998) argue that a CEO negotiates his power with the board over time, and that his bargaining position increases with past and current share values. If duality is seen as a consolidation of power in the CEO's hands, then their paper suggests that the CEO obtains duality by previously identifying and investing in positive NPV projects. ${ }^{18}$ Their argument, unfortunately, produces two possible predictions. If the CEO arrives at his decisions to invest optimally with the help of non-management directors, there will be a positive relation between duality and the amount of options granted. Conversely, if a more powerful CEO requires less monitoring and less advice from non-management directors, then there will be a

\footnotetext{
${ }^{18}$ Faleye (2003) provides indirect support of Hermalin and Weisbach's argument in that he reports that dual CEOs on average, have been CEOs at their firms for 12.4 years while non-dual CEOs, on average,
} 
negative association between duality and options awards. We define duality as an indicator variable equal to one if there is duality, and zero otherwise.

\subsection{CEO pay components, director pensions, and other control variables}

\subsubsection{CEO pay component}

Bryan et al. (2000) and Core et al. (1999), in two very different papers, use many of the variables in sections 4.1 through 4.3 to measure the relation between CEO compensation, CEO stock option grants, and agency, economic, and corporate governance variables. Thus, to ensure that our director options model in equation (1) is not merely capturing the board's decisions on determining CEO stock option grants, we include the dollar value of CEO stock option grants over total CEO compensation as a control variable. For example, it is entirely possible that directors devise their pay packages to mimic the CEO's because directors either are captured by the $\mathrm{CEO}$, or because the board wants to signal to outsiders that their pay incentives are congruent with the CEO's pay incentives (or visa-versa). In either case, we expect a positive relation between director stock option grants and CEO stock option grants.

We include the CEO's dollar value of restricted stock as a percentage of total CEO compensation as a control variable. Bryan et al. (2000) show that determinants behind CEO stock grants are opposite those for CEO stock option grants due to the differences in payoff schedules between securities. Using the same rationale we use for options, we predict a negative relation between director stock option grants and CEO stock grants.

\subsubsection{Non-management pension plan}


We include a dummy variable for whether non-management directors receive a pension from the firm upon retirement as directors of the firm. Pensions reward longevity and are not connected with how well the firm performs today or in the near future. Further, if a pension plan has a vesting period, non-vested non-management directors may feel constrained to advise managers against their wills because these directors want to remain on the board for the requisite period of time. These arguments suggest a negative association between the use of director stock option grants and the existence of a director pension plan.

\subsubsection{Ownership structure}

We add two equity ownership variables as controls. We include the average percentage of shares owned by each director and predict a negative association between this variable and director stock options. As director ownership increases, director agency costs should diminish since their interests are relatively aligned with shareholders through their equity positions in the firm. In addition, firms may time stock option grants in accordance with the number of shares that directors currently have (Core and Guay, 1999).

We also include institutional holdings, measured as the percent of total shares owned by institutional shareholdings, but make no prediction on the direction of association between this variable and stock option grants. Porter (1992) asserts that because institutional investors trade actively on short-term earnings, managers tend to focus on short-term performance. To counterbalance this effect, incentive-based compensation for independent directors may be required, suggesting a positive coefficient on the percent of shares owned by institutions. Conversely, Shleifer and Vishny (1986) argue that institutional investors have fewer free rider problems relative to fragmented individual shareholders, thus enabling them to engage in 
continuous information gathering of corporate affairs and ensuring that managers undertake value-maximizing investment projects. This line of reasoning suggests a negative association between institutional shareholdings and the amounts of stock awarded to non-management board members.

\subsubsection{Other controls}

We also control for possible industry and year affects that are not captured by our variables. Accordingly, we include year and industry-indicator variables into our analyses.

\subsection{Descriptive statistics - Agency costs, economic variables, board characteristics, and control variables}

Table 2 contains descriptive statistics for our independent variables. We divide the table into four panels - agency costs, economic determinants, board characteristics; and alternate compensation and equity ownership. We present the mean, median, and standard deviation for each variable.

Panel A provides information on the agency costs proxies. The first test of the optimal contracting theory is to see if agency costs differ substantially across firms. The data in panel A are consistent with this assumption. The standard deviations for each of the variables (with the exception of leverage) is as least as high as the variable's mean. For example, the standard deviation on market-to-book ratio (MTB) is 7.876, but MTB has a mean of 2.961 and a median of 2.244. Similarly, the standard deviation on firm size is 30.255 , compared to a mean of 11.165 . Thus, we conclude there are significant variations in agency costs among firms. 
Panel A's means and medians also paint a picture of the type of firms in our sample. The mean and median market-to-book ratios are over two. The mean R\&D expenditures (over firm value) is 0.016 , with a median of 0.001 . The latter indicates that over half of the sample firmyears had some research and development expenditures, an indicator that our time period presented companies with manifold growth opportunities. The median leverage ratio (debt-toassets) is 0.352 , a reflection of the relatively low interest rates over the time period. Firm size is skewed to the right; the mean is over $\$ 11$ billion while the median is $\$ 1.72$ billion. ${ }^{19}$ The mean and median Altman Z-score indicates that the majority of the firms in the sample are financially healthy, although the relatively large standard deviation (5.494) indicates that some firms are in danger of becoming insolvent according to this particular measure of bankruptcy risk.

The two economic determinants, free cash flows and the marginal tax rate, are shown in Panel B. The mean and median free cash flows (free cash flows-to-firm value) are 0.056 and 0.055 , respectively. Thus, most of the sample firms exhibit positive free cash flows, a finding consistent with our overall sample containing relatively large firms (e.g., see Fama and French, 2001). The median marginal tax rate is 0.35 and reflects the marginal federal tax rate on corporations.

Panel C has the board attributes. For our average firm, approximately twenty percent of board members are inside directors, whereas approximately two-thirds are independent members. The inside percentage is similar to Klein (1998), who uses a sample of S\&P 500 firms for the 1992-1993 period; but the percentage of independent directors is greater than the 58 percent reported for her sample. The increase in the percentage of independent directors is an outcome

\footnotetext{
${ }^{19}$ The difference between mean and median suggests non-normality. Thus, we convert firm size to a natural logged value throughout our tests.
} 
of the recent scrutiny placed on boards to be more independent of management. ${ }^{20}$ Similarly, the median board size has nine members, down substantially from twelve members in 1992-1993 (Klein, 1998). One interesting time-trend comparison can be made on the proportion of firms that have the CEO serving as the Chairman of the Board. For our sample, 74.77 percent of firms have this board structure. Core et al. (1999), using a sample of 495 observations between 1982 and 1984, report that 75.6 percent of their sample firms have CEO duality. Thus, there appears to be little movement over time in separating the board chairmanship from the CEO. We also note that over one-third of independent directors are over 62 years of age.

Panel D has summary statistics on CEO compensation and equity ownership. Consistent with prior studies, we find widespread usage of CEO option grants, and that these grants have large monetary values. For all firms, the median stock option grant value is $\$ 3.1$ million. For only those firms granting options, the median value is $\$ 4.0$ million. In contrast, fewer firms use CEO stock grants as a component of CEO pay - the median grant for all firms is zero and the median value for those using grants is $\$ 0.7$ million. Finally, the average director (including inside directors) owns approximately one percent of the firm's equity and financial institutions own 62 percent of the average firm's equity.

\section{Results - Director Option Grants Mix}

\subsection{Correlation Statistics}

We present correlations among the director compensation, agency costs, board characteristics, and control variables for the panel data over the 1997-2002 period in Table 3. Several correlations are worth noting. First, the correlation between the dollar mix of director

${ }^{20}$ Although we do not report it, the increase in independent directors comes at the expense of affiliated or "gray" directors. 
stock option grants and the dollar mix of CEO stock option grants is 0.23 , significant at the 0.01 level. Thus, director and CEO option grants are highly correlated. Yet, the magnitude of the correlation suggests that many alternate factors determine the amounts of options that directors and CEOs receive. This is an important finding as it suggests that our analysis is not a replication of those papers examining which factors drive CEO stock option grants. ${ }^{21}$ In addition, we find (not tabulated) that while 75 percent of the firm-years include option awards as part of the CEO's compensation package, only 70 percent of the observations use option grants for nonmanagement directors. The magnitude of the correlation, nevertheless, supports our decision to include CEO stock options as an explanatory variable into our analyses.

Second, we note a significantly negative correlation between director stock option grants and director stock grants - the correlation coefficient is -0.48 , significant at the 0.01 level. Similarly, CEO stock option grants and CEO stock grants have a correlation coefficient of -0.20 , significant at the 0.01 level. These results parallel those reported by Bryan et al. (2000), suggesting a trade-off between granting options and restricted stock.

Third, the first column of Table 3 shows statistically significant correlations between director option grants and many of our independent variables. In particular, we report significant correlations for many of our agency costs - market-to-book, R\&D, firm size, and leverage. In contrast, we find weaker correlations between director option grants and board attributes. For example, percentage of inside directors, percentage of independent directors, and CEO duality, all have correlations under the absolute value of 0.10 .

Finally, as expected and previously documented, many of the independent factors are significantly correlated with each other. For example, firm leverage is correlated with firm size

\footnotetext{
${ }^{21}$ Later in the paper, we present other evidence supporting this assertion.
} 
$(\rho=0.43)$ and with Altman's Z-score $(\rho=-0.47)$. As a result, we use a multivariate approach to explain the determinants of director stock option grants.

\subsection{Tobit Results}

We present our multivariate empirical results in Table 4. The dependent variable is the average dollar value percentage of stock option grants in the non-management directors'total pay package. The table presents coefficients and t-statistics on agency costs, other economic determinants, board characteristics, alternate compensation, and equity ownership variables. We do not report the coefficients for the year and industry-indicator variables as they are not germane to this study. The one exception is that we present the coefficient and t-statistic on the industry-indicator, Utility, since we predict a negative association between stock option grants and a regulatory environment.

The Tobit results demonstrate that director stock option grants are cross-sectionally related to agency costs. Firms with higher investment opportunities, as proxied by the firm's R\&D expenditures and market-to-book ratio, and less financially distressed firms, as proxied by Altman's Z-score, are more likely to use higher amounts of director stock options as a form of director payment. We interpret these findings as evidence that firms with better and more risky investment opportunities align director incentives to encourage these investments. Larger firms, utilities, and more leveraged firms are less likely to use director stock options, which we interpret as a reflection of the required amounts of external monitoring by shareholders needed by these firms. We note that all coefficients are statistically significant at the 0.01 level, except for the market-to-book ratio and firm size, which are significant at the 0.10 or 0.05 levels. Thus, the evidence strongly supports the optimal contracting view vis-à-vis agency costs. 
The empirical results on the economic determinants yield statistically significant coefficients on free cash flows $(\mathrm{p}<0.05)$ and the marginal tax rate $(\mathrm{p}<0.10$ or 0.05$)$. The coefficient on free cash flows is negative, supporting the view that less liquid firms are more likely to use optionbased compensation rather than cash compensation, since option-based compensation conserves cash. This finding is consistent with Fama and French's (2001) empirical observation that high growth opportunity firms have negative cash flows from operations and exhibit high asset growth rates, but is inconsistent with Jensen's (1986) free cash flow theory of over-investment. The statistically significant coefficient on the marginal tax rate suggests that tax considerations play role in the board's decision to issue stock option grants.

Three of the four board of director variables produce statistically significant coefficients. Consistent with expectations, firms with smaller boards and younger board members use a higher mix of stock options in total compensation packages. We interpret these results as support for the argument that active, advisory boards are more likely to provide non-management directors incentives consistent with the goal of having managers invest in more risky investment projects. The strength of the significantly negative coefficient on CEO duality is surprising given the a priori lack of directional predictions. Ex post, it appears that, in the presence of duality, directors do not need higher incentives to spur the CEO into making optimal investing decisions. This result is consistent with Brickley et al.'s (1987) contention that CEO duality is negatively related to agency costs. The coefficient on the percentage of inside directors is insignificantly different from zero.

At this point, it is useful to compare our results with those of Core et al. (1999). Core et al. (1999) test for the association between CEO compensation and corporate governance variables. They examine the association for compensation levels as well as a mix of pay, which is the ratio 
of equity-based pay over total pay. Although we examine options only, the gist of their mix variable (the dependent variable) is similar to ours. Core et al. (1999) test for the association between their mix and eight board structure variables - of these eight factors, four are very similar to ours. The most striking difference between our and their results is in the directions of the overlapping variables. For example, whereas they find a significantly negative coefficient on the percentage of insiders, we find an insignificantly positive coefficient. Similarly, we report a significantly negative coefficient on board size in contrast to their significantly positive coefficient.

Our difference in board coefficients relates to the differing premises in both papers. Core et al. (1999) hypothesize and conclude that CEOs are overly-paid for their services, and that this excess pay is exacerbated under poor corporate governance monitoring conditions. We maintain that non-management directors are not overcompensated to the degree that CEOs are. For example, the average value of non-management stock option awards for firms using these options is $\$ 77,194$. This compares with $\$ 4.0$ million for CEO stock option awards. Thus, our analyses of determinants behind the granting of stock options do not suffer from an excess pay problem documented or asserted by other studies.

Two of the three alternative compensation variables are significant at conventional levels and support our hypotheses. The coefficient on CEO stock option grants is $0.210(0.243)$ for the model with R\&D (market-to-book), significant at the 0.01 level. This finding is consistent with two arguments. First, despite CEO excess compensation, similar factors determine the use of stock options to compensate CEOs and directors. Second, it is important to control for CEO stock option grants to ensure that our dependent variable, director stock option grants, is not acting as a proxy for the CEO's grants. We find no significant association between CEO stock 
grants and director options, lending further support that CEO pay and director pay are not necessarily linked. In contrast, the coefficient on the independent director pension indicator is significantly negative at the 0.01 level. This result supports the optimal contracting theory in that pension plans and options provide opposite incentives. Finally, we note a significantly positive coefficient on our control variable, institutional ownership, and an insignificant coefficient on director ownership.

\section{Director stock option grants and future investments and firm performance}

We have demonstrated, thus far, two of the three required links behind the hypothesis that firms use director stock options in a way that is consistent with optimal contracting. First, as shown in Table 2, agency costs differ significantly across firms. Second, director stock option grants are significantly associated with these agency costs (Table 4). However, the third link, not yet shown, is that director stock grants are positively associated with managers taking on more risky, higher NPV projects. It is to this association that we next turn.

\subsection{Empirical Specifications}

We test for the third link by examining two strands of outcomes. First, we examine the associations between current stock option awards and management's actions. If non-management stock options result in the firm taking on more risky NPV projects, then we expect a positive relation between director stock option grants and risky investments. We examine two investment variables, the change in next year's R\&D expenditures and the change in next year's capital expenditures. If expenditures on long-term assets and research and development represent managers' successful searches for positive NPV projects, we predict an increase in both variables 
after directors receive stock option grants. Following Guay (1999), we also examine next year's variability of stock returns as a measure of the riskiness of the firm's investments. If riskincreasing projects result in higher stock volatility (e.g., higher systematic and non-systematic risk), we expect a positive relation between stock return variances and director stock option grants

Next, we examine the associations between current stock option awards and firm performance. Specifically, we ask whether stock options induce managers to invest in positive NPV projects, instead of over-investing in negative NPV projects. We employ four performance measures. Next year's return on assets (ROA) is an accounting profitability measure, The remaining three performance measures are market-based - next year's Tobin's Q ratio, next year's market return on investments (Jensen, 1993), and this year's market returns. We choose contemporaneous stock returns instead of future returns because efficient market theory predicts that markets immediately price external affects (for example, increases in future investments) associated with the issuance of non-management stock option grants.

A negative coefficient on stock option grants for the regressions on next period's ROA, Tobin's Q, Jensen productivity, respectively, and current stock returns is consistent with managers over-investing in negative NPV projects. A non-negative coefficient on stock option grants would be consistent with managers investing in positive NPV projects. A zero coefficient suggests that in the aggregate, firms use non-management director stock options to effectively induce the "correct" amount of positive investments. A positive coefficient is consistent with firms, in the aggregate, under-utilizing non-management director stock options, but is consistent with the conjecture that stock options are associated with positive NPV projects. We also note that a non-zero coefficient on stock option grants can be due to empirical misspecifications, for 
example our failure to properly control for omitted correlated variables, endogeneities between stock options and firm performance, or errors-in-the-variables. We conduct robustness tests to examine these empirical issues.

We use regression analysis to measure the associations between non-management stock option grants and the future investment and performance variables. Our basic regression is:

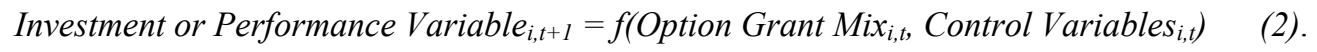

Change in $R \& D$ is the change in next year's $R \& D$ expenditures scaled by beginning period's total assets. For example, if current director stock option grants is for the year 1998, change in $R \& D$ is equal to $R \& D$ expenditures for 1999 minus $R \& D$ expenditures for 1998 divided by total assets at the beginning of 1999 (end of 1998). Change in capital expenditures is the percent change in the firm's next year's capital expenditures, as disclosed in the investing section of the firm's cash flow statement. Next period's variance of stock returns is the variance of daily raw stock returns in the following year.

Return on assets is EBITDA scaled by total assets. Jensen productivity, an adaptation of Jensen's (1993) measure, is intended to evaluate the productivity of the firm's long-term investments. It is equal to the change in market value of equity minus a benchmark return on investments, all scaled by market value of equity. We measure the benchmark return as cash flows from investing activities times the firm's cost of capital. Following Jensen (1993), a constant cost of capital of 8 percent is assumed for all firms. Alternative rates of 6 percent and 10 percent produce qualitatively the same results. Next year's Tobin's Q is the end of next year's market value of equity divided by the end of next year's book value of equity. Current market returns are this year's raw market returns. 
Option grant mix (\%Option Comp) is dollar option awards scaled by total compensation, and the control variables include board characteristics and other controls that are highlighted in the finance literature.

We use four classes of control variables. Board characteristics and board ownership factors control for competing corporate governance mechanisms. Our choice of which board variables to include in each regression is influenced by Yermack (1996), Klein (1998), Vafeas (1999a), Core et al. (1999) and Moyer et al. (1996), who examine the relation between investment or performance measures and board attributes.

Next, we use firm specific attributes to control for cross-sectional economic determinants of investment and performance. These variables are the firm's market-to-book ratio, leverage, firm size, return on assets, prior market returns, and an asset turnover ratio. We also include industry and yearly dummy variables. Again, the choice of the economic controls is from prior published studies.

Third, we include the percentage of options in the CEO's executive pay package. Our primary reason for including this variable is to control for possible affects that pay incentives have on CEOs. Moreover, in Table 4, we find that our independent variable of interest, director stock options, is highly correlated with the CEO's stock option percentage.

Finally, we include the lagged value of the dependent variable into each regression, respectively, as a final control variable. For the regressions on next year's investment or performance variable, this is the current value; for the regression on this year's stock return, it is last year's stock return. The reason for including the lagged variable is to control for potential specification problems that (1) investment decisions and performance factors may be correlated 
over time, and (2) director stock option grants may be a function of this year's investment decisions or firm performance.

OLS allows for correlations among the explanatory variables and provides a vehicle for assessing the incremental contribution of each variable and the overall explanatory power of all independent variables. In a later section, we also use a two-stage least squares (2SLS) methodology to control for endogeneity between each dependent variable and option grant mix. As we show, the results with the 2SLS methodology are qualitatively the same as those we report using OLS. ${ }^{22}$

\subsection{Results}

\subsubsection{Future Investment Decisions}

We present the OLS results in Table 5. Columns (1) and (2) show the coefficients and tstatistics for the regressions on changes in $R \& D$ and changes in capital expenditures. The coefficient on director stock option grants is 0.008 , significant at the 0.01 level for the regression on future changes in R\&D. For the regression on future changes in capital expenditures, the coefficient on director stock option awards is 0.186 , significant at the 0.01 level. Both results support the optimal contracting theory in that an increase in director stock option grants this period is associated with an increase in investment spending in the next period. Board size is insignificantly different from zero in both models, \%inside directors is significantly positive at the 0.10 level for the regression on the change in capital expenditures, and the economic controls vary in significance. The coefficient on CEO option grants is significantly positive at the 0.01

\footnotetext{
${ }^{22}$ Core et al. (1999) use a two-stage least squares methodology to assess linkages between agency costs, CEO packages, and firm performance. Bowen et. al (2002) use a similar methodology to establish linkages between earnings manipulation, corporate governance variables and firm performance.
} 
level for the regression on $\mathrm{R} \& \mathrm{D}$, but is insignificant for the regression on capital expenditures. These findings support the view that CEO equity induces greater investments in risky projects (R\&D), but also supports our hypothesis that after controlling for CEO incentive pay, there is a positive relation between director options and future investments.

\subsubsection{Future Stock Return Volatility}

We present two regressions on stock return volatility. For model 3, \%Option comp (dir) is defined as before. For Model 3a, we use an indicator variable for the presence or absence of stock options in non-management director compensation. We include model 3a because option values are a function of future stock return variability in the Black-Scholes model. This may cause a spurious correlation between the value of stock options (\%option comp - dir) and the variance of returns. Using the indicator variable in model $3 \mathrm{a}$ mitigates this potential misspecification.

The regressions on stock return variances are consistent with stock option grants being related to future volatility of returns. In model 3, the coefficient on the percentage of stock option grants is significant at the 0.05 level. Similarly, in model 3a, the use of director stock option grants is associated with greater future variability of stock returns. Its coefficient too is significant at the 0.05 level. In addition, we report a significantly positive coefficient on CEO options. The director and CEO option findings are consistent with Guay (1999), who demonstrates a positive association between stock-return variability and the convexity of CEO stock options. In tandem, our paper's and Guay's (1999) results support the view that stock option grants are associated with managers undertaking more risky projects. Moreover, the significantly positive coefficient on \%inside director and the significantly negative coefficients 
on board size, duality, and director ownership are negative at the 0.01 or 0.05 levels, suggesting that advisory boards are associated higher with directors undertaking risky projects

\subsubsection{Future and Current Firm Performance}

Model 4 presents the regression on return on assets (ROA), a test of the link between current stock option grants and future firm accounting performance. The coefficient on stock option grants is significantly positive at the 0.05 level. Consistent with previous studies, the market-to-book ratio is significantly positive while firm size is significantly negative. ROA is related also to the asset turnover rate, a finding consistent with Core et al. (1999) and Ou and Penman (1989). ${ }^{23}$

Models 5 through 7 examine the association between firm performance and director stock option grants. In column 5, we relate director stock options to next year's Jensen's investment productivity level. We find the coefficient on director stock option grants to be significantly positive at the 0.05 level, a finding consistent with the hypothesis that director stock options are associated with higher future firm performance. In column 6, we find a contemporaneous positive relation between stock returns and the granting of director stock options; the coefficient on \%option comp (dir) is significantly positive at the 0.01 level. In column 7 , we examine the relation between Tobin's Q and director stock option grants. Like the previous two performance measure regressions, we find a significantly positive coefficient on director stock option grants.

One interesting finding for models 5 through 7 is the inconsistent signs and significance levels for the coefficient on CEO stock option awards. The coefficient is insignificantly positive

\footnotetext{
${ }^{23}$ Asset turnover ratio is sales divided by average total assets. Ou and Penman (1989) find this to be a significant predictor of future earnings. Core et al. (1999) finds a significant correlation between three and five-year future ROA and sales, but no relation between next year's ROA and sales.
} 
for the regression on Jensen's measure, significantly negative for the regressions on current stock returns, but significantly positive for the regression on Tobin's Q. These mixed results are consistent with Core et al.'s (1999) assertion that many CEOs earn excess compensation.

The positive coefficients on \%Option comp in regressions 4 through 7 are consistent with the view that non-management stock options are associated with positive NPV projects. However, while these findings support the view that directors encourage managers to invest in value-enhancing projects, they also are consistent with the notion that in the aggregate directors underutilize stock option grants as an investment incentive tool. That is, in equilibrium, the coefficients on stock option grants would be zero. Alternatively, an explanation for the positive coefficients is that our empirical regressions are misspecified. One possible source of misspecification is that performance measures and non-management director stock options are endogenously determined. We try to control for these endogeneities by including the lagged performance measure in each regression. The significant coefficients on $\mathrm{ROA}_{t}$ for the regression on $\mathrm{ROA}_{\mathrm{t}+1}$, Market-to-book $\mathrm{t}_{\mathrm{t}}$ for the regression on Market-to-book ${ }_{\mathrm{t}+1}$, and Returns $\mathrm{t}_{\mathrm{t}-1}$ for the regression on Returns $\mathrm{s}_{\mathrm{t}}$ support the hypothesis that non-management director stock options and firm performances are co-determined. We further control for this phenomenon by using a twostage least squares simultaneous equation methodology in the next section.

\subsubsection{Summary Results}

Overall, the findings in Table 5 support the third link in the optimal contracting theory. Namely, we find evidence that current stock option grants for non-management directors are positively related to future investments, firm risk, and firm performance, after controlling for economic determinants, alternative corporate governance mechanisms, and CEO stock option 
grants. The positive relation between current stock option grants and future changes in $R \& D$ and capital expenditures is consistent with stock options acting as incentives for managers to invest more heavily. The positive correlation between stock option grants and future volatility of stock returns supports the view that these investments are more risky. Finally, the non-negative coefficients on stock option awards for the firm performance regression are consistent with these firms not over-investing in risky projects. The positive coefficients, however, are also consistent with either firms, in aggregate, underutilizing stock option grants or possible misspecifications of the regression models. We turn to these issues next.

\section{Sensitivity Analyses}

\subsection{Non-management director stock option awards: Errors-in-the-variable}

In proxy statements, firms disclose components of CEO compensation and components of non-management director compensation. However, whereas firms must give option prices and expiration dates for CEO stock option grants, they do not necessarily disclose these details for non-management director stock option grants. We assume in our main tests that the nonmanagement director options have strike prices equal to their respective CEOs and that the maturities equal 10 years, which is the usual case for CEO stock option grants. As robustness tests, we use the average stock price for each firm over the corresponding fiscal year as an estimate of the strike price and we shorten the estimated maturity to 5 years. The basic tenor of our regression results remains unchanged.

We also recognize the possibility of spurious correlations in some statistical models due to functional relations. For instance, the relation between the variance of future stock returns and the current period's stock option awards (scaled by total compensation) may not capture the 
functional relation that exists in the Black-Scholes model. In addition, the value of long-term stock option grants may be overstated due to the non-diversification of the director's portfolio, which may include large amounts of cash, stock, and options from the company on whose board he or she serves (Meulbroek, 2001; Hall and Murphy, 2002). Therefore, we estimate all regression models with an indicator variable for the existence of stock options grants. Generally, our results remain the same as those reported in the discussion of our main results with the exception of the market-to-book model (column 7 in Table 5) where the coefficient on the indicator for stock option grants becomes insignificantly positive. Additionally, the significance levels for the indicator variable weaken but are still statistically significant at conventional levels for the Jensen and Returns models (columns 5 and 6 in Table 5). Thus, the measurement issues pertaining to stock option grants may dampen the interpretation of our results for columns $5-7$ in Table 5. The control variables generally maintain significance levels similar to those reported in Table 5.

\subsection{Independent Variable Definitions}

We attempt to capture via proxies a number of important constructs. We recognize the limitations of our results that may be attributable to measurement error, and therefore conduct numerous robustness checks on our independent variables, including normalizing by alternative measures.

Firm size is the log of firm assets. Alternately, we use the log of market value of equity at the beginning of the year. Free cash flows are operating income before depreciation less the sum of income tax, interest and dividends scaled by market value. Instead, we define free cash flows as operating cash flows minus investing cash flows divided by market value. Our 
empirical results with these two specifications are qualitatively the same as those reported throughout the paper.

We also use variations of our board characteristics. Instead of the percent of inside directors, we use the percent of independent directors. In table 4, the coefficients on the percent of inside directors are insignificantly different from zero. When we substitute the percent of independent directors, we arrive at the same results. Finally, the empirical results are invariant to whether we use board size or the logged value of board size in our analyses.

\subsection{Two-stage Least Square Methodology}

Table 5 uses an ordinary least squares (OLS) methodology to examine the links between future investment or firm performance variables and non-management director stock option awards. OLS treats director stock option grants as an exogenous variable, and does not take into account that many of the factors affecting firm performance may also be influencing the size of the director stock option grants. One solution to this potential problem is to use a two-stage least squares methodology, which allows for endogeneities between investment/performance and director stock options. The advantage of using a 2SLS methodology is that in light of endogenous variables, it produces more consistent estimators. However, as Greene (1990) points out, it is often found that the OLS estimator is surprisingly close to the structural estimator and in some cases the OLS estimator is more precise in a mean squared error sense. Nevertheless, we re-estimate equation (2) using a 2 SLS method, and then compare the coefficients and t-statistics with this model against the OLS model to see if there are marked differences in interpretations.

In the first stage, we estimate the percentage of stock option grants based on the following estimated (OLS) regression: 
Dir Stock Option Grants G $_{i}=\Sigma \alpha_{i}$ agency costs $s_{i}+\Sigma \beta_{i}$ economic determinants $+\Sigma \gamma_{i}$ Board

attributes $_{i},+\Sigma \delta_{i}$ CEO stock option grants $_{i}+\Sigma \zeta_{i}$ control variables $_{i}$,

where the estimated coefficients on the independent variables $\left(\alpha_{i}{ }^{\prime} \mathrm{s}, \beta_{i}{ }^{\prime} \mathrm{s}, \gamma_{i}{ }^{\prime} \mathrm{s}, \delta_{i}{ }^{\prime} \mathrm{s}\right.$, and $\zeta_{i}$ 's $)$ are those reported in Table 6, Panel A. We use the same independent variables in equation (3) as we used in our Tobit model with R\&D expenditures in as reported in Table 4. The prime difference is that 2SLS uses OLS for both stages. As discussed in the previous section, Tobit models are more appropriate when the dependent variable is truncated at zero. However, our OLS results reported in Table 6 are very similar to the Tobit results shown in Table 4, mitigating the concerns over the OLS model used in the two-stage approach.

In the second stage, we use the fitted director stock option grants and other control variables to examine the association between director stock option grants and future investment, risk, and firm performance variables. In order to compare the second stage results with the OLS findings in Table 5, we use the same independent variables as before. Table 6, Panel B presents the second stage results. The overall conclusion is that the 2SLS approach produces results that are qualitatively the same as those reported in Table 5 for the OLS regressions. For example, the coefficient on director options for the regression on $\triangle \mathrm{R} \& \mathrm{D}$ is $0.011(\mathrm{t}=4.95)$ using the 2SLS method and is $0.008(\mathrm{t}=4.84)$ using OLS. Similarly, the coefficient on the variance of returns is $3 \times 10^{-4}(\mathrm{t}=5.10)$ in model 3 using the 2SLS method and is $2 \times 10^{-4}(\mathrm{t}=3.14)$ for the OLS method. In fact, we find little differences in both coefficient magnitude and statistical significance for director stock option grants. Thus, the mean and standard errors of the estimators are little affected by whether we use an OLS or a 2SLS methodology. 


\section{Additional Analysis: Non-management Director Restricted Stock Grants}

\subsection{Restricted Stock Awards and the Optimal Contracting Theory}

Director compensation packages generally contain two types of contingent equity securities, stock option grants and restricted stock awards. Restricted stock is similar to stock options in that it can be viewed as an option with a zero strike price (Ofek and Yermack 1997). However, there are three institutional differences between the two forms of compensation. More important, there are marked differences in investing incentives between the two types of equity instruments.

Restricted stock grants are distinguished from stock option awards through financial accounting, tax, and dividend treatments. Current accounting rules mandate restricted stock awards to be expensed ratably over the restriction period (ABP Opinion No. 25). In contrast, SFAS 123 gives firms the ability to forego expensing stock options in the income statement. Under SFAS 123, firms can either treat stock option grants as a compensation expense in the income statement, or they can present a "pro forma" earnings-per-share in their footnotes as if they had expensed these grants. ${ }^{24}$ For U.S. income tax purposes, restricted stock awards provide deferred (future) tax deductions to the firm upon vesting. Stock option awards may or may not be tax deductible to the firm. Those options that are classified as "non-qualified" provide future tax deductions to the firm when the options are exercised, but options that are classified as incentive stock options do not. Further, whereas stock options typically are not dividend protected, restricted stock generally comes with both dividend protection and voting rights, commencing on the grant date (Kole 1997).

The most distinguishing feature between the two forms of equity-based pay is the non-

\footnotetext{
${ }^{24}$ The Financial Accounting Standards Board has issued an "exposure draft" that, if enacted as an accounting standard, would mandate the expensing of stock options.
} 
zero strike price for options against the implicit zero exercise price for restricted stock. Both option holders and restricted stockholders must be compensated for taking on an added risk; otherwise, they will be less likely to recommend risky, yet value-increasing, projects, i.e., the "underinvestment problem" (Smith and Stulz 1985). However, the disparity between exercise prices translates into different payoff functions. Stock options' have a payoff structure that is convex in stock price, whereas restricted stock's zero strike price creates a linear payoff schedule.

These differences in payoff schedules have given rise to a group of recent papers comparing the relative costs and efficiencies of using stock options against using restricted stock grants. Meulbroek (2001) and Hall and Murphy (2002) argue that stock options are more expensive to use than restricted stock grants. Feltham and $\mathrm{Wu}(2001)$ theoretically show that restricted stock contracts dominate option-based contracts when managers affect the mean of the outcome. In contrast, Lambert and Larcker (2004) present a model in which stock options generally dominate restricted stock when managers' efforts affect both the mean and variance of the firm's investments. From an empirical point of view, Bryan et al. (2000) show differences in the economic determinants for stock options versus restricted stock in the CEO's compensation package.

All of these papers examine the stock options-restricted stock debate from the point of view of the firm's executives. Most of these studies assume risk averse managers with relatively non-diversified portfolios. Since CEOs and upper management derive large amounts of their wealth from their employment, these assumptions are reasonable. Non-management directors, while risk averse, generally derive less of their wealth from their director pay packages. Nevertheless, these papers provide three testable hypotheses related to the optimal contracting 
theory for non-management restricted stock grants. First, similar to Bryan et al. (2000), we expect non-management director restricted stock grants to have different economic determinants from non-management stock option grants. Specifically, because restricted stock grants are less likely to induce risk-taking than stock option grants, we expect a non-positive relation between agency costs and the use of restricted stock option grants for non-management directors. Next, we propose that non-management restricted stock grants will result in lower levels of future investments in R\&D and capital expenditures, as well as lower levels of future variance in stock returns. Third, we propose that restricted stock grants will have little to negative affects on current stock returns or future firm performance. These three hypotheses are consistent with the optimal contracting theory in that they predict that the mix of restrictive stock grants in nonmanagement directors' pay package induce the firm to partake in less risky, but positive (or nonnegative) NPV projects.

\subsection{Data}

In Panel A of Table 1, we present the dollar and relative values of restricted stock over the 1997 through 2002 time period. In dollar terms, average restricted stock grants range between $\$ 12,915$ (1999) and \$16,504 (2002) In percentage terms, average restricted stock grants remain relatively flat over our time period, ranging between 14.2 percent to 15.2 percent of total non-management director compensation. These numbers contrast sharply with stock option grants, which are larger in both nominal and relative terms, and which rise generally over our sample period.

In Panel B of Table 1, we demonstrate that the use of restricted stock grants vary across industries in ways that are predictable with stock grants providing less risk-taking incentives than 
stock option grants. As the table shows, restricted stock is most prevalent for utilities and petroleum firms and least used by service companies. Utilities, in general, have less risky investment horizons and lower agency costs than other firms.

\subsection{Models and Empirical Results}

We use the same empirical analyses for restricted stock grants that we used for stock option grants. To analyze the determinants behind the incidence of restricted stock grants, we fit a Tobit model, in which the ratio of non-management director restricted stock grants to total compensation is the dependent variable and the same independent variables as described in section 4 (and in Table 4) are used. For this analysis, we add one new independent value, the

percentage of stock options in the non-management director's pay package. We predict a negative coefficient on this variable, since we expect strong trade-offs between the use of stock options and stock grants. Next, we use OLS to regress next period's investment variables $\left(\Delta \mathrm{Rnd}_{\mathrm{t}+1}\right.$ and $\left.\Delta \mathrm{CapEx}_{\mathrm{t}+1}\right)$ and variance of stock returns on the mix of restricted stock awards to total compensation and the control variables as described in section 6 and Table 5. Finally, we use OLS to regress next period's accounting return $\left(\mathrm{ROA}_{\mathrm{t}+1}\right)$, market-based performance (Jensen $_{t+1}$, Tobin's $\mathrm{Q}_{\mathrm{t}+1}$ ) and contemporaneous market returns (Returns $\mathrm{t}_{\mathrm{t}}$ ) on the percentage of restricted stock awards and control variables that are also described in Table 5 and in section 6 .

\subsubsection{Tobit Model}

Table 7 contains the results for our Tobit model. Overall, the empirical findings in Table 7 are consistent with our hypothesis that restrictive stock grants are not used primarily to mitigate the firm's agency costs. In models 1 and 2 , we report insignificantly negative 
coefficients on RND (the coefficient is -0.241 , with a t-statistic equal to -1.02) and the market-tobook ratio (the coefficient is -0.001 , with a t-statistic equal to -1.17 ). This sharply contrasts with the results in Table 4 for stock option grants, in which both RND and market-to-book were significantly positive. We have a similar finding for the coefficients on Utility - utilities are less inclined to use stock option grants (Table 4), but are relatively indifferent from other industries in their use of restricted stock grants (Table 7). The coefficients on the z-score and firm size are significantly different from zero for the Tobit model on restrictive stock, but the signs of these coefficients are opposite from those reported for the model on stock option grants. Similarly, the coefficients on firm leverage are of the opposite sign for the model on restrictive stock vis-àvis the model on stock option grants. However, the significance levels on the coefficients for leverage for the restrictive stock models are markedly less than those reported for the stock option grants model.

Unlike stock option grants, we find no significant relation between the incidence of restricted stock grants and either of the economic variables, free cash flow and the marginal tax rate. Restricted stock is related to three of the four board characteristics, but many of associations are different than those reported for stock options. In Table 7, the use of restricted stock is negatively related to the percent of inside directors on the board and to the percent of directors over the age of 62 , but is positively related to board size. There is no significant coefficient on CEO duality. The findings on inside directors, board size, and CEO duality are inconsistent with those found for stock options. Only the result on director age is consistent between both models.

Perhaps the most striking result in Table 7 are the coefficients on director stock options, which are -0.866 , with a t-statistic of -21.09 for model 1 and -0.870 , with a t-statistic of -21.69 
for model 2. These findings support the literature's views that stock options and restricted stock are viewed as substitute equity securities in pay packages. This finding also contrasts with Elson's (1996) view that stock and options act similarly in providing incentives to directors.

In summary, the results reported in Table 7 support two related hypotheses. First, they support the view the determinants behind restricted stock and stock option grants to nonmanagement directors are different from each other. Second, the weak coefficients on the firms' agency costs are consistent with the hypothesis that restricted stock grants are not issued primarily to mitigate these agency costs.

\subsubsection{Future Investments, Future Variability, and Firm Performance}

Table 8 contains the OLS results on the regressions of changes in future investments, next year's stock volatility, and firm performance on non-management director restricted stock grants and other control variables. These regressions are analogous to those presented in Table 5 with the exception that we substitute restricted stock grants for stock option grants.

Columns 1 and 2 measure the association between changes in investments and restricted stock. Unlike the results reported in Table 5, which show a positive association between stock option grants and changes in future investments, we find an insignificantly negative coefficient on restricted stock awards for the regression on $\Delta \mathrm{RND}_{\mathrm{t}+1}$ and a marginally significantly negative coefficient for the regression on $\Delta \mathrm{CapEx}_{\mathrm{t}+1}$. Similarly, in column 3, we report a significantly negative coefficient on restricted stock for the regression on next period's variance of stock returns, which is opposite to the coefficient found for the regression using stock option grants. These findings are consistent with the hypothesis that stock grants do not give directors the 
incentive to urge managers to invest in risky projects. They also support the view that restricted stock and stock options provide directors with different incentives to invest.

Columns 4 through 7 investigate the relation between firm performance and the issuance of stock grants. Recall that in Table 5, we document a positive relation between stock option grants and firm performance, suggesting that stock options provide positive incentives to directors to invest in positive NPV projects. In contrast, the results in Table 7 produce an insignificantly positive coefficient on restricted stock for the regression on accounting performance (column 4) and insignificantly negative coefficients on restricted stock for the regressions on current and future market performances (columns 5 through 7). Thus, no tangible association is found between restricted stock grants and firm performance.

\subsubsection{Summary}

The optimal contracting theory predicts that firms' director pay packages are constructed to mitigate firm's agency costs, resulting in optimal uses of pay components to induce managers to invest in positive NPV projects. Under this theory, and given the different payoff functions of stock options and restrictive stock, we predict different relations between stock options and restrictive stock as they relate to (1) the firm's agency costs, (2) managers' future investment behavior, (3) variability of future returns, and (4) firm performance. The results in Table 8 support this view.

Stock option grants are positively related to equity agency costs and negatively related to debt agency costs. In contrast, restricted stock grants are either not related to agency costs or have opposite associations from those found for stock option grants. Stock option grants are positively related to changes in future investments, as measured by research and development 
expenditures and capital expenditures. Restricted stock grants are not related to future changes in $R \& D$ and are negatively associated with changes in future capital expenditures. While stock option grants are positively associated with future stock volatility, restricted stock grants have a negative relation with this variable. Finally, restricted stock grants have no tangible association with current or future firm performance. This latter result suggests that directors use restricted stock grants optimally as it pertains to investing in positive NPV projects.

In summary, the results on restricted stock grants supports the optimal contracting theory and lends further support to our conclusion that stock option grants, too, are used optimally.

\section{Summary and Conclusions}

This study documents evidence in favor of the view that non-management director stock option grants are consistent with optimal contracting. We test this hypothesis by demonstrating three links. First, we show that agency costs vary substantially across firms. Next, we find significant associations between the dollar amount of option grants-to-overall director compensation and the degree of agency costs. This finding supports the hypothesis that boards set their directors' compensation packages to mitigate the firms' agency costs. In this part of the analysis, we control for other board characteristics, other economic determinants, the CEO's pay mixes (options and stock grant mixes) and other control variables. Finally, we find significantly positive relations between non-management stock option grants and future investments, volatility of returns and firm performance. These results are robust to different measures of director option mixes, and are invariant to whether we control for possible endogeneities between stock option grants and investment and firm performance measures, 
We also document relations between board characteristics and director option grants. Consistent with Fama and Jensen (1983), we propose that boards serve both monitoring and advisory roles. We predict that boards more involved in an investment advisory role more likely will issue stock option grants to its non-management directors than boards that primarily are monitors of top management. Our findings support this prediction. Specifically, we find significantly negative associations between the non-management director option mix and board size and directors nearing retirement. We interpret these findings as being consistent with the optimal contracting theory.

Our findings speak to two current and related issues, best board practices and board effectiveness. Both issues have surfaced due to the number of recent corporate failures and to firms' reactions to the Sarbanes-Oxley Act of 2002 and the exchanges' revisions in corporate governance listing requirements. Our findings on the link between options and equity agency costs provide evidence that best board practices, as they pertain to director options, vary across firms. For firms with high growth opportunities, director options are a viable choice. Conversely, firms that are regulated or with low growth opportunities may wish to eschew giving their directors options. These findings strongly suggest that boards should not conform to a common standard, but should assess how their boards can be structured to work best for their shareholders.

Our findings on the link between options and future investing decisions, firm risk, and firm performance suggest an association between non-management director options and board effectiveness. However, our study does not differentiate between two plausible explanations about these findings. Do stock options induce non-management directors to prod managers more strongly into investing in risky positive NPV projects? Or, do boards structure their director 
compensation packages to signal to the market their intentions to direct managers on how to invest? Most likely, both explanations overlap and are reasonable partial interpretations of our findings. 


\section{Appendix}

The value of non-management directors' stock option awards is estimated each year using the following model:

$$
\text { Option }=\text { Option }_{\text {share }} \times \mathrm{N}=\left[\mathrm{Pe}^{-\mathrm{dT}} \Theta\left(\mathrm{d}_{1}\right)-\mathrm{Xe}^{-\mathrm{rT}} \Theta\left(\mathrm{d}_{2}\right)\right] \times \mathrm{N},
$$

where Option ${ }_{\text {share }}$ denotes the per share value of a stock option award, and

$\mathrm{N}=$ the number of stock options granted each year during the test period 1997-2002;

$\mathrm{P}=$ the stock price on the date of CEO stock option grants, which assumes that the director grants are made concurrently (As noted in the text, we use average prices over the fiscal year as a robustness check.);

$\mathrm{X}=$ the exercise price of stock options which is assumed to be equal to $\mathrm{P}$ on the grant date, since firms almost always set the exercise price equal to the current stock price [Murphy, 1998];

$\mathrm{d}=$ the expected dividend yield over the life of the options, estimated as the prior year's dividend per share divided by the year end's stock price;

$\mathrm{r}=$ risk-free rate, measured by the annual yield on ten-year U.S. Treasury bonds;

$\sigma=$ the expected stock return volatility, estimated as the annualized standard deviation of sixty monthly stock returns ending at the end of the prior year;

$\mathrm{T}=$ the time to expiration set equal to ten years, since most stock options have a ten year option maturity [Matsunaga, 1995; Murphy, 1998];

$\Theta=$ the cumulative normal distribution function; and

$\mathrm{d}_{1}=\left[\ln (\mathrm{P} / \mathrm{E})+\left(\mathrm{r}-\mathrm{d}+0.5 \sigma^{2}\right) \mathrm{T}\right] / \sigma \mathrm{T}^{1 / 2}$ and $\mathrm{d}_{2}=\left[\ln (\mathrm{P} / \mathrm{E})+\left(\mathrm{r}-\mathrm{d}-0.5 \sigma^{2}\right) \mathrm{T}\right] / \sigma \mathrm{T}^{1 / 2}$. 


\section{References}

Accounting Principles Board (APB) Opinion No. 25. Accounting for Stock Issued to Employees. Financial Accounting Standards Board Original Pronouncements. John Wiley \& Sons, New York.

Agrawal, Anup, Charles Knoeber, 1996. Firm performance and mechanisms to control agency problems between managers and shareholders. Journal of Financial and Quantitative Analysis $31,377-397$.

Altman, Edward, 1993. Corporate financial distress and bankruptcy. Wiley and Sons, New York. Anderson, Ronald, and John Bizjak, 2000. An empirical examination of the role of the CEO and the compensation committee in structuring executive pay. Working paper, American University.

Baber, W. R., Janakiraman, S. N., and Kang, S. 1996. Investment opportunities and the structure Formatted: German (Germany) of executive compensation. Journal of Accounting and Economics 21: 297-318.

Baliga, Ram B., R. Charles Moyer, and Ramesh S. Rao, 1996. CEO duality and firm performance: what's the fuss?" Strategic Management Journal 17, 41-53.

Beasley, Mark, 1996. An empirical analysis of the relation between the board of director composition and financial statement fraud. Accounting Review 71, 443-465.

Bebchuk, Lucian A., Jesse M. Fried, and David I. Walker, 2002. Managerial power and rent extraction in the design of executive compensation. University of Chicago Law Review 69, 751846.

Berle, Adolf A., and Gardiner C. Means, 1932. The Modern Corporation and Private Property, Macmillan, New York.

Bhagat, Sanjai, and Bernard S. Black, 2002. The non-correlation between board independence and long-term firm performance. Iowa Journal of Corporate Law 27, 248-260.

Bizjak, J. M., Brickley, J. A., and Coles, J. L. 1993. Stock-based incentive compensation and investment behavior. Journal of Accounting and Economics 16: 349-372.

Black, Fischer and Myron Scholes, 1973. The pricing of options and corporate liabilities. Journal of Political Economy 81, 637-654.

Bowen, Robert M., Shivaram Rajgopal, and Mohan Venkatachalam, 2003. Accounting discretion, corporate governance and firm performance. Working paper, University of Washington and Duke University. 
Brick, Ivan E., Oded Plamon, and John K. Wald, 2002. CEO compensation, director compensation, and firm performance: evidence of cronyism. Working paper, Rutgers Business School - Newark and New Brunswick.

Bryan, Stephen, Lee-Seok Hwang, and Steve Lilien, 2000. CEO stock-based compensation: an empirical analysis of incentive-intensity, relative mix, and economic determinants. Journal of Business, October 2000: 661-693.

Bryan, Stephen, and Lee-Seok Hwang, 1997. CEO Compensation in a Regulatory Environment: An Analysis of the Electric Utility Industry. Journal of Accounting, Auditing, and Finance, Summer 1997: 223-251

Bushman, Robert M., Indjejikian, R.J. and Abbie Smith, 1996. CEO compensation: The role of individual performance evaluation. Journal of Accounting and Economics 21, 161-193.

Carcello, Joseph V., and Terry L. Neal. 2000. Audit committee composition and auditor reporting. The Accounting Review 75, 453-468.

Carcello, Joseph V., and Terry L. Neal. 2003. Audit committee characteristics and auditor dismissals following "new" going-concern reports. The Accounting Review 78, 95-118.

Carpenter, Jennifer. 1998. The exercise and valuation of executive stock options. Journal of Financial Economics 48: 127-158.

Clinch, Greg, 1991. Employee compensation and firms' research and development activity. Journal of Accounting Research 29, 59-78.

Core, John E., and Wayne Guay, 1999. The use of equity grants to manage optimal equity incentive levels. Journal of Accounting and Economics 28, 151-184.

Core, John E., Robert W. Holthausen, and David F. Larcker, 1999. Corporate governance, chief executive officer compensation, and firm performance. Journal of Financial Economics 51, 371406.

Cuny, C. and Jorion, P. 1995. Valuing executive stock options with an endogenous departure decision. Journal of Accounting and Economics 20: 193-205.

Dechow, P.M., Hutton, A. P., and Sloan, R. G. 1996. Economic consequences of accounting for stock-based compensation. Journal of Accounting Research 34 (Supplement): 1-20.

Demsetz, Harold and Kenneth Lehn, 1985. The structure of corporate ownership: causes and consequences. Journal of Political Economy 93, 1155-1177.

Delaware General Corporation Law, 1999. Prentice Hall. 
Eaton, J., Rosen, H.S., 1983. Agency, delayed compensation, and the structure of executive remuneration. Journal of Finance 38, 1489-1505.

Eisenberg, T., S. Sundgren, and M. Wells, 1998. Larger board size and decreasing firm value in small firms. Journal of Financial Economics 48, 35-54.

Elson, Charles, 1996. Director Compensation and the Management-Captured Board - The History of a Symptom and a Cure, SMU Law Review, Volume 50: 127-140.

Faleye, Olubnmi, 2003. Does one hat fit all? The case of corporate leadership structure. Working paper, Northeastern University - Boston Ma.

Fama, Eugene F., and Kenneth R. French, 2001. Disappearing dividends: changing firm characteristics or lower propensity to pay? The Journal of Financial Economics 60: 3-44.

Fama, Eugene F. and Michael C. Jensen, 1983. Separation of ownership and control. Journal of Law \& Economics 26, 301-325.

Feltham, G., and M. Wu, 2001. Incentive efficiency of stock versus options, Review of Accounting Studies, 6, 7-28.

Financial Accounting Standards Board Statement No. 123. Accounting for Stock-Based Compensation. www.fasb.org.

Fisch, Jill E., and Caroline M. Gentile, 2003. The qualified legal compliance committee: Using the attorney conduct rules to restructure the board of directors. Duke Law Journal 53, forthcoming.

Gaver, Jennifer J. and Kenneth M. Gaver, 1993. Additional evidence on the association between the investment opportunity set and corporate financing, dividend and compensation policies. Journal of Accounting and Economics 16, 125-160.

Gilson, Stuart, 1990. Bankruptcy, boards, banks, and blockholders: Evidence on changes in corporate ownership and control when firms default. Journal of Financial Economics 27, 315353.

Gilson, Stuart, and Michael Vetsuypens, 1993. CEO compensation in financially-distressed firms: An empirical analysis. Journal of Finance 48, 425-458.

Goyal, V., and C. Park, 2002. Board leadership structure and CEO turnover. Journal of Corporate Finance 8, 49-66.

Graham, John, 1996, Proxies for the corporate marginal tax rate, Journal of Financial Economics 42, 187-221.

Greene, William, 1990. Econometric Analysis. Macmillan, New York. 
Grossman, S., Hart, O., 1982. Corporate financial structure and managerial incentives. In: McCall, J.J. (Ed.), The Economics of Information and Uncertainty. University of Chicago Press, Chicago.

Guay, Wayne R. 1999. The sensitivity of CEO wealth to equity risk: an analysis of the magnitude and determinants. Journal of Financial Economics 53, 43-71.

Hall, Brian J., and Kevin J. Murphy. 2002. Stock options for undiversified executives. Journal of Accounting and Economics 33: 3-42.

Hermalin, Benjamin E., and Michael S. Weisbach, 1998. Endogenously chosen boards of directors and their monitoring of the CEO. American Economic Review 88, 96-118.

Huddart, S. 1994. Employee stock options. Journal of Accounting and Economics 18: $207-$ 231.

Jensen, M., 1986. Agency costs of free cash flow, corporate finance and takeovers. American Economic Review 76, 323-329.

Jensen, Michael, 1993. The modern industrial revolution, exit, and the failure of internal control systems. Journal of Finance 48, 831-880.

Jensen, Michael C. and William Meckling, 1976. Theory of the firm: managerial behavior, agency costs, and ownership structure. Journal of Financial Economics 3, 305-360.

Jensen, Michael C. and K. Murphy, 1990. Performance pay and top-management incentives. Journal of Political Economy 98, 225-264.

John, Teresa and Kose John, 1993. Top-management compensation and capital structure. Journal of Finance 48, 949-974.

Joskow, P., Rose, N., and Wolfram, C. 1996. Political constraints on executive compensation: evidence from the electric utility industry. RAND Journal of Economics 27: 165-182.

Kole, S.R., 1997. The complexity of compensation contracts. Journal of Financial Economics 43, 79-104.

Klein, April, 1998, Firm performance and board committee structure, The Journal of Law \& Economics 41, 275-303.

Klein, April. 2002. Audit committee, board of director characteristics, and earnings management. Journal of Accounting \& Economics 33: 375-400.

Lambert, Richard A., and David F. Larcker, 2004. Stock Options, Restricted Stock, and Incentives. Working Paper. The Wharton School, University of Pennsylvania. 
Lewellen, W., Loderer, C., Martin, K., 1987. Executive compensation and executive incentive problems: an empirical evidence. Journal of Accounting and Economics 9, 287-310.

Lipton, M., and J. Lorsch, 1992. A modest proposal for improved corporate governance.

Business Lawyer 48, 59-77.

Lublin, J., 2003. More Work, More Pay. Special Report: Corporate Governance. The Wall Street Journal, February 24.

Mace, Myles L., 1986. Directors: Myths and Realty. Harvard Business School Press, Boston.

Matsunaga, S. R. 1995. The effects of financial reporting costs on the use of employee stock options. The Accounting Review 70: 1-26.

Mehran, Hamid, 1995. Executive compensation structure, ownership, and firm performance. Journal of Financial Economics 38, 163-184.

Meulbroek, Lisa K., 2001. The efficiency of equity-linked compensation: Understanding the full cost of awarding executive stock options. Financial Management 30, 5-30.

National Association of Corporate Directors, 1995. Report of NACD Blue Ribbon Commission on Director Compensation.

New York Business Corporation Law, 1999. Prentice Hall.

NYSE. 2003. Final NYSE Corporate Governance Rules. www.nyse.com.

Ofek, Eli, and David Yermack, 2000. Taking stock: Does equity-based compensation increase managers ownership. Journal of Finance 55, 1367-1384.

Oppermann, Peter. 1997, Director Compensation in Paying for Performance: A Guide to Compensation Management, edited by Peter T. Chingos, John Wiley \& Sons, Inc. New York.

Ou, Jane. and Stephen Penman. 1989. Financial statement analysis and the prediction of stock returns. Journal of Accounting and Economics 11, 295-329.

Perry. R. Tod, 1999. Incentive compensation for outside directors and CEO turnover. Unpublished working paper, University of North Carolina at Chapel Hill.

Porter, Michael, 1992. Capital choices: changing the way America invests in industry. Boston, MA: Council on Competitiveness/Harvard Business School.

Scholes, M., and Wolfson, M. A. 1992. Taxes and Business Strategy: A Planning Approach. Englewood Cliffs, New Jersey: Prentice-Hall. 
Shleifer, Andrei, Robert Vishny, 1986. Large shareholders and corporate control. Journal of Political Economy 94, 461-488.

Smith, Clifford W., and Rene Stulz. 1985. The determinants of firms' hedging policies. Journal of Financial and Quantatitive Analysis 20, 391-405.

Smith, Clifford, and Ross Watts, 1992. The investment opportunity set, and corporate financing, dividend, and compensation policies. Journal of Financial Economics 32, 263-292.

Strickland, D., K. Wiles, and M. Zenner, 1996. A requiem for the USA: Is small shareholder monitoring effective? Journal of Financial Economics 40, 319-338.

Stulz, R., 1990. Managerial discretion and optimal financing policies. Journal of Financial Economics 26, 3-28.

Theil, Henri, 1971. Principles of Econometrics. John Wiley \& Sons. New York, New York.

Thompson, Randall, 1999, Preemption and Federalism in Corporate Governance: Protecting Shareholder rights to Vote, Sell, and Sue. Law and Contemporary Problems, Vol. 62, No. 3: 215242

Vafeas, Nikos, 1999a. Board meeting frequency and firm performance. Journal of Financial Economics 53, 113-142.

Vafeas, Nikos, 1999b. Determinants of the adoption of director incentive plans. Journal of Accounting, Auditing and Finance, 453-474.

Wahal, S., 1996. Pension fund activism and firm performance. Journal of Financial and Quantitative Analysis 31, 1-23.

Wruck, Karen H., 1990. Financial distress, reorganization, and organizational efficiency. Journal of Financial Economics 27, 419-444.

Yermack, David, 1995. Do corporations award CEO stock options effectively? Journal of Financial Economics 39, 237-269.

Yermack, David, 1996. Higher market valuation of companies with a small board of directors. Journal of Financial Economics 40, 185-211.

Yermack, David, 2003. Renumeration, retention, and reputation incentives for outside directors. Journal of Finance forthcoming. 
Table 1

Non-management Director Compensation by Year and Industry

Panel A: Non-management Director Compensation by Year (Means)

\begin{tabular}{|c|c|c|c|c|c|c|c|c|c|c|c|c|c|}
\hline Year & $\mathrm{N}$ & $\begin{array}{c}(\$) \\
\text { Annual } \\
\text { Retainer }\end{array}$ & $\begin{array}{l}(\$) \\
\text { Fee per } \\
\text { Mtg }\end{array}$ & $\begin{array}{c}\# \\
\text { Mtgs }\end{array}$ & $\begin{array}{c}(\$) \\
\text { Cash } \\
\text { Comp } \\
\text { (Dir) }\end{array}$ & $\begin{array}{c}(\$) \\
\text { Option } \\
\text { Comp } \\
\text { (Dir) }\end{array}$ & $\begin{array}{c}(\$) \\
\text { Stock } \\
\text { Comp } \\
(\text { Dir) }\end{array}$ & $\begin{array}{c}(\$) \\
\text { Total } \\
\text { Comp } \\
(\mathrm{Dir})\end{array}$ & $\begin{array}{c}\% \\
\text { Option } \\
\text { Comp } \\
\text { (Dir) }\end{array}$ & $\begin{array}{c}\% \\
\text { Stock } \\
\text { Comp } \\
\text { (Dir) }\end{array}$ & $\begin{array}{c}\% \\
\text { Option } \\
\text { Firms }\end{array}$ & $\begin{array}{l}\% \\
\text { Stock } \\
\text { Firms }\end{array}$ & $\begin{array}{c}\% \\
\text { Pension } \\
\text { Firms }\end{array}$ \\
\hline 1997 & 1127 & 19,278 & 1,046 & 7.13 & 26,654 & 41,518 & 13,733 & 81,930 & 32.9 & 14.9 & 60.8 & 36.9 & 17.7 \\
\hline 1998 & 1103 & 19,999 & 1,075 & 7.23 & 27,551 & 43,184 & 14,257 & 84,992 & 33.3 & 15.2 & 63.7 & 39.2 & 13.1 \\
\hline 1999 & 1149 & 20,199 & 1,073 & 7.30 & 27,917 & 60,192 & 12,915 & 101,025 & 34.4 & 14.8 & 65.6 & 38.8 & 10.9 \\
\hline 2000 & 1170 & 21,123 & 1,087 & 7.44 & 29,104 & 69,386 & 14,449 & 112,940 & 38.1 & 14.9 & 69.8 & 38.7 & 9.2 \\
\hline 2001 & 1229 & 21,427 & 1,101 & 7.03 & 29,065 & 66,455 & 13,956 & 109,477 & 41.4 & 14.2 & 72.2 & 35.8 & 6.7 \\
\hline 2002 & 1198 & 23,172 & 1,129 & 7.20 & 31,137 & 55,335 & 16,504 & 102,976 & 39.0 & 14.4 & 72.7 & 37.0 & 4.6 \\
\hline
\end{tabular}


Table 1, continued

Panel B: Non-management Director Compensation by Industry (Means)

\begin{tabular}{|c|c|c|c|c|c|c|c|c|c|c|c|c|c|}
\hline Indus. & $\mathrm{N}$ & $\begin{array}{c}(\$) \\
\text { Annual } \\
\text { Retainer }\end{array}$ & $\begin{array}{c}(\$) \\
\text { Fee per } \\
\text { Mtg }\end{array}$ & $\begin{array}{c}\# \\
\text { Mtgs } \\
\end{array}$ & $\begin{array}{c}(\$) \\
\text { Cash } \\
\text { Comp } \\
(\mathrm{Dir}) \\
\end{array}$ & $\begin{array}{l}(\$) \\
\text { Option } \\
\text { Comp } \\
\text { (Dir) }\end{array}$ & $\begin{array}{c}(\$) \\
\text { Stock } \\
\text { Comp } \\
\text { (Dir) } \\
\end{array}$ & $\begin{array}{c}(\$) \\
\text { Total } \\
\text { Comp } \\
\text { (Dir) }\end{array}$ & $\begin{array}{c}\% \\
\text { Option } \\
\text { Comp } \\
\text { (Dir) } \\
\end{array}$ & $\begin{array}{c}\% \\
\text { Stock } \\
\text { Comp } \\
\text { (Dir) }\end{array}$ & $\begin{array}{c}\% \\
\text { Option } \\
\text { Firms } \\
\end{array}$ & $\begin{array}{c}\% \\
\text { Stock } \\
\text { Firms } \\
\end{array}$ & $\begin{array}{c}\% \\
\text { Pension } \\
\text { Firms }\end{array}$ \\
\hline Comm & 93 & 27,811 & 1,020 & 8.94 & 36,766 & 64,557 & 17,777 & 119,100 & 39.5 & 14.2 & 65.5 & 39.7 & 15.0 \\
\hline Fin & 886 & 22,102 & 1,116 & 7.61 & 30,042 & 50,884 & 20,955 & 101,882 & 33.4 & 16.0 & 59.4 & 35.7 & 13.4 \\
\hline MM & 3322 & 21,396 & 1,056 & 7.04 & 28,834 & 61,277 & 13,173 & 103,293 & 38.9 & 14.1 & 73.1 & 37.4 & 9.5 \\
\hline Other & 308 & 21,854 & 1,129 & 6.42 & 28,983 & 29,512 & 10,051 & 68,547 & 28.2 & 12.4 & 62.0 & 34.1 & 6.5 \\
\hline Petrol & 63 & 30,375 & 1,181 & 8.47 & 40,731 & 9,668 & 38,698 & 89,098 & 10.4 & 30.4 & 25.4 & 71.4 & 22.2 \\
\hline Retail & 592 & 19,147 & 1,111 & 6.17 & 25,981 & 48,184 & 13,561 & 87,431 & 38.4 & 13.3 & 68.9 & 30.4 & 4.1 \\
\hline Serv & 804 & 17,359 & 1,108 & 7.25 & 25,281 & 101,945 & 10,478 & 137,706 & 51.7 & 9.3 & 79.6 & 23.0 & 3.7 \\
\hline Trans & 447 & 21,865 & 1,233 & 6.90 & 30,044 & 23,831 & 15,198 & 69,074 & 27.9 & 15.2 & 65.7 & 42.9 & 16.5 \\
\hline Utility & 461 & 19,188 & 997 & 9.40 & 28,475 & 15,749 & 15,804 & 60,029 & 15.0 & 26.8 & 33.4 & 71.4 & 22.1 \\
\hline
\end{tabular}

Board compensation variables are as follows: Annual Retainer is the annual retainer paid to non-management directors; Fee per Mtg is the fee per meeting paid to non-management directors; \#Mtgs is the number of director meetings during the year; Cash Comp(Dir) is the total cash component of nonmanagement director compensation, calculated as Annual Retainer plus the Fee per Mtg times \#Mtgs; Option Comp (Dir), value of non-management director stock option compensation, measured as the number of options granted during the year times the Black Scholes value per option; Stock Comp(Dir), value of non-management director stock compensation, measured as the number of shares of stock granted during the year times the average stock price; Total Comp(Dir), the sum of Cash Comp, Option Comp, and Stock Comp; \%Option Comp (Dir), Option Comp divided by Total Comp; \% Stock Comp (Dir), Stock Comp divided by Total Comp; \% Option Firms, the percentage of firms that grant stock options to non-management directors; \%Stock Firms, the percentage of firms that grant shares of stock to non-management directors; \%Pension Firms, the percentage of firms that provide pensions for nonmanagement directors. The industries are as follows: Comm (communications); Fin (financial services); MM (manufacturing and mining); Petrol (petroleum); Serv (services, including computer services and technology), Trans (transportation); Utility (utility). 


\begin{tabular}{|c|c|c|c|}
\hline \multicolumn{4}{|c|}{$\begin{array}{c}\text { Table } 2 \\
\text { Descriptive Statistics for the Pooled Sample }\end{array}$} \\
\hline $\mathrm{N}=6976$ & mean & median & std. dev. \\
\hline \multicolumn{4}{|l|}{ Panel A: Equity Agency Costs } \\
\hline Market to Book & 2.961 & 2.244 & 7.876 \\
\hline RND & 0.016 & 0.001 & 0.036 \\
\hline Leverage & 0.348 & 0.352 & 0.209 \\
\hline Firm Size ( $\$$ billions) & 11.165 & 1.717 & 30.255 \\
\hline Z-score & 4.082 & 2.890 & 5.494 \\
\hline \multicolumn{4}{|l|}{ Panel B: Economic Determinants } \\
\hline Free Cash Flows & 0.056 & 0.055 & 0.055 \\
\hline Marginal Tax Rate & 0.315 & 0.350 & 0.077 \\
\hline \multicolumn{4}{|l|}{ Panel C: Board Characteristics } \\
\hline \%Inside Directors & 0.215 & 0.182 & 0.120 \\
\hline \%Independent Directors & 0.640 & 0.667 & 0.176 \\
\hline CEO Duality (percentage of firms) & 74.770 & & \\
\hline Age & 59.456 & 59.545 & 3.384 \\
\hline$\%>62$ Years & 0.384 & 0.375 & 0.172 \\
\hline Board Size & 9.698 & 9.000 & 2.677 \\
\hline \multicolumn{4}{|c|}{ Panel D: Alternate Compensation and Equity Ownership (all Comp variables in \$ 000s) } \\
\hline Option Comp (CEO) (all firms) & $3,123.605$ & 876.434 & 9,826 \\
\hline Option Comp (CEO) (option granting firms; $\mathrm{N}=5229$ ) & $4,012.983$ & $1,474.974$ & 10,976 \\
\hline Stock Comp (CEO) (all firms) & 595.88 & 0.000 & 8,889 \\
\hline Stock Comp (CEO) (stock granting firms; N=1643) & $2,530.440$ & 676.350 & 18,190 \\
\hline \%Ownership (Dir) & 1.128 & 0.257 & 2.349 \\
\hline$\%$ Ownership (Institutional) & 62.003 & 63.840 & 17.112 \\
\hline
\end{tabular}

Market to Book, the market value of equity divided by the book value of equity; $\boldsymbol{R N D}$, research and development expense scaled by firm value, measured as the sum of the market value of equity and the book value of debt; Leverage, the book value of debt to total assets, Firm Size, book value of total assets; Z-score, Altman's Z-score based on a combination of five ratios from Altman (1993); Free Cash Flows, operating income before depreciation less the sum of income tax, interest and dividends scaled by market value of the firm, measured as the market value of equity plus the book value of debt; Marginal Tax Rate, the firm's simulated marginal tax rate (from Graham (1996)); \%Inside Directors, percentage of directors who are also employees of the firm; \%Independent Directors, percentage of directors who are independent; CEO Duality, percentage of firms in which the Chair and the CEO are the same individual; $\boldsymbol{A g e}$, average age of firms' directors; $\%>\mathbf{6 2}$, percentage of firms' directors who are older than 62; Board Size, total number of directors; Option Comp (Dir), value of non-management director stock option 
compensation, measured as the number of options granted during the year times the Black Scholes value per option; Stock Comp (Dir), value of non-management director stock compensation, measured as the number of shares of stock granted during the year times the average stock price; Option Comp(CEO), value of CEO stock option compensation; Stock $\operatorname{Comp}(\boldsymbol{C E O})$, value of CEO stock compensation; \% Director Ownership, the percentage of shares outstanding owned by all directors; \% Institutional Ownership, the percentage of shares outstanding owned by institutions who file Form 13-F. 
Table 3

Correlations Among Proxies for Equity Agency Costs, Economic Determinants, Corporate Governance Mechanisms,

and Alternate Compensation and Equity Ownership

\begin{tabular}{|c|c|c|c|c|c|c|c|c|c|c|c|c|c|c|c|c|c|}
\hline & $\begin{array}{c}\text { \% Option } \\
\text { Comp } \\
\text { (Dir) }\end{array}$ & $\begin{array}{l}\text { \% Stock } \\
\text { Comp } \\
\text { (Dir) }\end{array}$ & $\begin{array}{c}\text { Market to } \\
\text { Book }\end{array}$ & RND & Leverage & Firm Size & $Z$-score & $\begin{array}{l}\text { Free } \\
\text { Cash } \\
\text { Flow }\end{array}$ & $\begin{array}{l}\text { Marg. Tax } \\
\text { Rate }\end{array}$ & $\begin{array}{c}\text { \% Inside } \\
\text { Dir. }\end{array}$ & $\begin{array}{c}\text { \% Indep. } \\
\text { Dir }\end{array}$ & CEO Dual. & Age & Board Size & $\begin{array}{c}\% \text { Option } \\
\text { (CEO) }\end{array}$ & $\begin{array}{c}\text { \% Stock } \\
\text { (CEO) }\end{array}$ & $\begin{array}{c}\text { \% Own. } \\
\text { (Dir) }\end{array}$ \\
\hline$\%$ Stock (Dir) & -0.48 & & & & & & & & & & & & & & & & \\
\hline MTB & 0.05 & 0.00 & & & & & & & & & & & & & & & \\
\hline RND & 0.19 & -0.12 & 0.01 & & & & & & & & & & & & & & \\
\hline Leverage & -0.32 & 0.22 & -0.12 & -0.25 & & & & & & & & & & & & & \\
\hline Firm Size & -0.18 & 0.31 & 0.02 & -0.21 & 0.43 & & & & & & & & & & & & \\
\hline Z-score & 0.24 & -0.13 & 0.17 & -0.01 & -0.47 & -0.23 & & & & & & & & & & & \\
\hline FCF & -0.06 & 0.02 & -0.07 & -0.29 & -0.03 & -0.03 & -0.11 & & & & & & & & & & \\
\hline MTR & -0.06 & 0.05 & 0.03 & -0.27 & 0.00 & 0.14 & 0.05 & 0.30 & & & & & & & & & \\
\hline$\%$ Inside Dir. & 0.09 & -0.17 & 0.02 & -0.00 & -0.24 & -0.20 & 0.15 & 0.00 & 0.00 & & & & & & & & \\
\hline$\%$ Indep. Dir. & -0.06 & 0.20 & -0.05 & 0.02 & 0.20 & 0.17 & -0.11 & 0.00 & -0.01 & -0.64 & & & & & & & \\
\hline CEO Duality & -0.09 & 0.09 & 0.00 & -0.06 & 0.11 & 0.15 & -0.03 & -0.01 & 0.03 & -0.06 & 0.13 & & & & & & \\
\hline Age & -0.14 & 0.02 & -0.03 & -0.05 & 0.14 & 0.13 & -0.06 & -0.02 & 0.02 & -0.13 & 0.07 & 0.02 & & & & & \\
\hline Board Size & -0.24 & 0.25 & 0.03 & -0.21 & 0.32 & 0.58 & -0.19 & -0.01 & 0.13 & -0.22 & 0.11 & 0.03 & 0.13 & & & & \\
\hline$\%$ Option (CEO) & 0.23 & -0.02 & 0.06 & 0.15 & -0.08 & 0.16 & 0.09 & -0.10 & -0.02 & -0.11 & 0.11 & -0.03 & -0.08 & 0.02 & & & \\
\hline$\%$ Stock (CEO) & -0.10 & 0.15 & 0.00 & -0.07 & 0.12 & 0.15 & -0.07 & 0.00 & 0.03 & -0.10 & 0.09 & 0.03 & 0.02 & 0.11 & -0.20 & & \\
\hline$\%$ Own (Dir) & 0.01 & -0.15 & 0.02 & -0.05 & -0.11 & -0.23 & 0.09 & 0.01 & -0.04 & 0.33 & -0.38 & -0.03 & -0.00 & -0.20 & -0.17 & -0.05 & \\
\hline$\%$ Own (Inst.) & 0.15 & 0.04 & 0.01 & -0.07 & -0.04 & 0.13 & 0.01 & 0.13 & 0.07 & -0.12 & 0.16 & 0.06 & -0.04 & -0.07 & 0.24 & 0.03 & -0.22 \\
\hline
\end{tabular}

Bold (italicized) font represents significance levels at the $0.01(0.05)$ levels. Cells contain Pearson correlations. Please refer to Tables 1 and 2 for variable definitions. 


\begin{tabular}{|c|c|c|c|c|c|}
\hline \multicolumn{6}{|c|}{ Table 4} \\
\hline \multicolumn{6}{|c|}{$\begin{array}{c}\text { Tobit Models of the Relation between the Percentage of Director Option Compensation } \\
\text { and Hypothesized Determinants }\end{array}$} \\
\hline Independent Variables & Expected Sign & Estimate & t-statistics & Estimate & t-statistics \\
\hline \multicolumn{6}{|l|}{ Agency Costs } \\
\hline RND & $(+)$ & 1.026 & $4.35^{* * *}$ & & \\
\hline Market to Book & $(+)$ & & & 0.008 & $1.73^{*}$ \\
\hline Leverage & $(-)$ & -0.147 & $-3.43^{* * *}$ & -0.195 & $-4.76^{* * *}$ \\
\hline Z-score & $(+)$ & 0.011 & $7.54^{* * * *}$ & 0.009 & $6.81^{* * * *}$ \\
\hline Utility & $(-)$ & -0.132 & $-4.10^{* * *}$ & -0.107 & -3.41 \\
\hline Firm Size & $(+,-)$ & -0.007 & $-1.94^{*}$ & -0.012 & $-2.04^{* *}$ \\
\hline \multicolumn{6}{|l|}{ Economic Determinants } \\
\hline Free Cash Flows & $(+,-)$ & -0.320 & $-2.18^{* *}$ & -0.463 & $-2.88^{* *}$ \\
\hline Marginal Tax Rate & $(-)$ & -0.111 & $-1.81 *$ & -0.220 & $-2.79^{* *}$ \\
\hline \multicolumn{6}{|l|}{ Board Characteristics } \\
\hline$\%$ Inside Directors & $(+)$ & -0.051 & -0.89 & -0.075 & -1.16 \\
\hline Board Size & $(-)$ & -0.024 & $-8.08^{* * *}$ & -0.026 & $-8.18^{* * *}$ \\
\hline$\%>62$ & $(-)$ & -0.135 & $-3.51^{* * *}$ & -0.129 & $-3.41^{* * *}$ \\
\hline CEO Duality & $(-)$ & -0.062 & $-4.28^{* * *}$ & -0.055 & $-3.93^{* * *}$ \\
\hline \multicolumn{6}{|l|}{ Other Pay and Controls } \\
\hline$\%$ Option Comp (CEO) & $(+)$ & 0.210 & $8.33^{\text {*** }}$ & 0.243 & $9.874^{* * * *}$ \\
\hline$\%$ Stock Comp (CEO) & $(-)$ & -0.072 & -1.41 & -0.054 & -1.07 \\
\hline Pension (Dir) & $(-)$ & -0.095 & $-4.26^{* * *}$ & -0.787 & $-3.70^{* * *}$ \\
\hline$\%$ Ownership (Inst) & $(+,-)$ & 0.115 & $4.95^{* * *}$ & 0.136 & $5.99^{* * *}$ \\
\hline \% Ownership (Dir) & $(-)$ & -0.003 & -0.44 & -0.003 & -0.94 \\
\hline
\end{tabular}

The dependent variable is \%Option Comp, measured as the value of non-management director stock options granted during the year (using the Black Scholes model) divided by total non-management compensation; $\boldsymbol{R N D}$ is research and development expense scaled by firm value; Market to Book is market value of equity divided by book value of equity; Leverage is the book value of debt to total assets; Z-score, is Altman's Z-score from Altman (1993); Utility is an indicator variable assigned a value of 1 if the firm is in the utility industry. Firm Size, the natural log of total assets; Free Cash Flows are operating income before depreciation less the sum of income tax, interest and dividends scaled by the firm's market value; Marginal Tax Rate is the firm's simulated marginal tax rate (following Graham, 1996); \%Inside Directors is the percentage of directors who are also employees of the firm; Board Size is the number of directors on the board; $\%>\mathbf{6 2}$ is the percentage of board members older than 62; CEO Duality is an indicator variable assigned a value of 1 if the firm's chair and CEO are the same individual; \%Option Comp (CEO) is the value of stock options granted during the year to the firm's CEO divided by total compensation; \%Stock Comp (CEO) is the value of restricted stock during the year to the firm's CEO divided by total compensation; Pension (Dir) is an indicator variable assigned a value of 1 if the firm has a pension plan for non-management directors; \%Ownership (Inst) is the log of the percentage of shares owned by institutional shareholders; \%Ownership (Dir) is the log of the average percentage of outstanding shares owned by all of the firm's board members; Reported t-statistics are robust to serial correlation and heteroscedasticity. $*, * *, * *=$ significant at the $0.10,0.05,0.01$ levels, respectively. 
Table 5

Ordinary Least Squares Models between Future Firm Characteristics and Board Stock Option Compensation and Board Characteristics

\begin{tabular}{|c|c|c|c|c|c|c|c|c|}
\hline Model & 1 & 2 & 3 & $3 a$ & 4 & 5 & 6 & 7 \\
\hline $\begin{array}{l}\text { Independent } \\
\text { Variables } \\
(\text { at period } \mathrm{t} \text { ) }\end{array}$ & $\Delta \mathrm{Rnd}_{\mathrm{t}+1}$ & $\Delta \mathrm{CapEx}_{\mathrm{t}+1}$ & $\begin{array}{l}\text { Variance } \\
\text { Returns }_{\mathrm{t}+1}\end{array}$ & $\begin{array}{l}\text { Variance } \\
\text { Returns }_{\mathrm{t}+1}\end{array}$ & $\mathrm{ROA}_{t+1}$ & Jensen $_{t+1}$ & Returns $_{\mathrm{t}}$ & $\begin{array}{c}\text { (Q) } \\
\text { Market-to- } \\
\text { book }_{\mathrm{t}+1}\end{array}$ \\
\hline $\begin{array}{l}\text { \%Option } \\
\text { Comp (Dir) }\end{array}$ & $\begin{array}{c}0.008 \\
(4.84)^{* * *}\end{array}$ & $\begin{array}{c}0.186 \\
(5.21)^{* * *}\end{array}$ & $\begin{array}{c}2 \times 10^{-4} \\
(3.14)^{* *}\end{array}$ & $\begin{array}{c}1 \times 10^{-4} \\
(2.97)^{* *}\end{array}$ & $\begin{array}{c}0.019 \\
(2.93)^{* *}\end{array}$ & $\begin{array}{c}0.074 \\
(2.45)^{* *}\end{array}$ & $\begin{array}{c}0.130 \\
(4.74)^{* * *}\end{array}$ & $\begin{array}{c}0.976 \\
(3.45)^{* *}\end{array}$ \\
\hline $\begin{array}{l}\text { \% Inside } \\
\text { Director }\end{array}$ & $\begin{array}{r}0.005 \\
(1.17)\end{array}$ & $\begin{array}{c}0.174 \\
(1.89)^{*}\end{array}$ & $\begin{array}{c}4 \times 10^{-4} \\
(2.65)^{* *}\end{array}$ & $\begin{array}{c}4 \times 10^{-4} \\
(2.69)^{* *}\end{array}$ & $\begin{array}{r}0.015 \\
(0.89)\end{array}$ & $\begin{array}{l}0.243 \\
(2.98)^{* *}\end{array}$ & $\begin{array}{l}-0.016 \\
(-0.22)\end{array}$ & $\begin{array}{c}0.241 \\
(0.32)\end{array}$ \\
\hline Board Size & $\begin{array}{l}-2 \times 10^{-4} \\
(-0.83)\end{array}$ & $\begin{array}{l}-0.002 \\
(-0.30)\end{array}$ & $\begin{array}{l}-5 \times 10^{-5} \\
(-5.42)^{* * *}\end{array}$ & $\begin{array}{l}-5 \times 10^{-5} \\
(-6.15)^{* * *}\end{array}$ & $\begin{array}{c}0.002 \\
(2.00)^{* *}\end{array}$ & & & $\begin{array}{c}0.113 \\
(2.77)^{* *}\end{array}$ \\
\hline CEO Duality & & & $\begin{array}{l}-9 \times 10^{-5} \\
(-2.23)^{* *}\end{array}$ & $\begin{array}{l}-1 \times 10^{-4} \\
(-2.45)^{* *}\end{array}$ & $\begin{array}{r}0.005 \\
(1.04)\end{array}$ & $\begin{array}{r}0.000 \\
(0.43)\end{array}$ & $\begin{array}{c}-0.000 \\
(-0.10)\end{array}$ & \\
\hline $\begin{array}{l}\text { \% Ownership } \\
\text { (Dir) }\end{array}$ & & & $\begin{array}{l}-1 \times 10^{-5} \\
(-1.86)^{*}\end{array}$ & $\begin{array}{l}-1 \times 10^{-5} \\
(-1.91)^{*}\end{array}$ & $\begin{array}{l}2 \times 10^{-4} \\
(0.21)\end{array}$ & $\begin{array}{r}0.002 \\
(0.39)\end{array}$ & $\begin{array}{c}0.004 \\
(1.07)\end{array}$ & $\begin{array}{c}0.164 \\
(4.02)^{* * *}\end{array}$ \\
\hline $\begin{array}{l}\text { Market-to- } \\
\text { book }\end{array}$ & $\begin{array}{l}8 \times 10^{-5} \\
(1.46)\end{array}$ & $\begin{array}{c}0.002 \\
(1.63)^{*}\end{array}$ & $\begin{array}{c}0.000 \\
(0.23)\end{array}$ & $\begin{array}{c}0.000 \\
(0.65)\end{array}$ & $\begin{array}{l}6 \times 10^{-4} \\
(3.46)^{* * * *}\end{array}$ & $\begin{array}{l}-0.001 \\
(-1.34)\end{array}$ & $\begin{array}{c}0.007 \\
(5.32)^{* * *}\end{array}$ & $\begin{array}{l}0.087 \\
(9.27)^{* * *}\end{array}$ \\
\hline Firm Size & $\begin{array}{l}4 \times 10^{-4} \\
(1.05)\end{array}$ & $\begin{array}{c}0.016 \\
(1.84)^{*}\end{array}$ & $\begin{array}{l}-3 \times 10^{-5} \\
(-2.12)^{* *}\end{array}$ & $\begin{array}{c}-0.000 \\
(-0.48)\end{array}$ & $\begin{array}{c}-0.006 \\
(-3.66)^{* *}\end{array}$ & $\begin{array}{c}0.012 \\
(1.97)^{* *}\end{array}$ & $\begin{array}{c}-0.006 \\
(-1.14)\end{array}$ & $\begin{array}{c}0.206 \\
(2.94)^{* *}\end{array}$ \\
\hline Leverage & & & $\begin{array}{l}-3 \times 10^{-5} \\
(-0.26)\end{array}$ & $\begin{array}{l}-2 \times 10^{-4} \\
(-1.66)^{*}\end{array}$ & & & & \\
\hline ROA & $\begin{array}{c}0.029 \\
(6.30)^{* * *}\end{array}$ & $\begin{array}{c}0.245 \\
(2.49)^{* *}\end{array}$ & & & $\begin{array}{c}0.506 \\
(18.98)^{* * *}\end{array}$ & $\begin{array}{c}0.223 \\
(2.69)^{* *}\end{array}$ & $\begin{array}{c}0.126 \\
(3.11)^{* *}\end{array}$ & $\begin{array}{c}5.245 \\
(6.71)^{* * *}\end{array}$ \\
\hline Asset Turnover & & & & & $\begin{array}{c}0.015 \\
(5.37)^{* * *}\end{array}$ & & & \\
\hline $\begin{array}{l}\text { Number } \\
\text { Segments }\end{array}$ & & & & & & & & $\begin{array}{l}-0.365 \\
(-2.81)^{* *}\end{array}$ \\
\hline $\begin{array}{l}\% \text { Option } \\
\text { Comp (CEO) }\end{array}$ & $\begin{array}{c}0.007 \\
(3.91)^{* * *}\end{array}$ & $\begin{array}{c}-0.027 \\
(-0.69)\end{array}$ & $\begin{array}{c}4 \times 10^{-4} \\
(5.83)^{* * *}\end{array}$ & $\begin{array}{l}1 \times 10^{-4} \\
(2.49)^{* *}\end{array}$ & $\begin{array}{c}0.002 \\
(0.26)\end{array}$ & $\begin{array}{r}0.040 \\
(1.20)\end{array}$ & $\begin{array}{c}-0.109 \\
(-3.71)^{* *}\end{array}$ & $\begin{array}{c}1.074 \\
(3.52)^{* *}\end{array}$ \\
\hline$\Delta$ Rnd & $\begin{array}{l}8 \times 10^{-4} \\
(0.93)\end{array}$ & & & & & & & $\begin{array}{c}0.448 \\
(3.40)^{* *}\end{array}$ \\
\hline$\Delta$ CapEx & & $\begin{array}{c}0.000 \\
(1.05)\end{array}$ & & & & & & $\begin{array}{l}-0.000 \\
(-0.59)\end{array}$ \\
\hline $\begin{array}{l}\text { Variance of } \\
\text { Returns }\end{array}$ & & & $\begin{array}{c}0.447 \\
(25.91)^{* * *}\end{array}$ & $\begin{array}{c}0.470 \\
(27.88)^{* * *}\end{array}$ & & $\begin{array}{c}-12.468 \\
(-1.44)\end{array}$ & & \\
\hline Jensen & & & & & & $\begin{array}{r}0.000 \\
(0.98)\end{array}$ & & \\
\hline Returns & & & & & & & $\begin{array}{c}-0.003 \\
(-1.68)^{*}\end{array}$ & \\
\hline Adj. $\mathrm{R}^{2}$ & 0.07 & 0.07 & 0.28 & 0.27 & 0.24 & 0.10 & 0.04 & 0.08 \\
\hline
\end{tabular}

The dependent variables are (without subscripts): $\Delta \boldsymbol{R} \boldsymbol{n d}$, change in RND scaled by total assets at the beginning of the period; $\triangle \boldsymbol{C a p E x}$, year to year percentage change in capital expenditures (from the investing section of the Statement of Cash flows); Variance of Returns, variance of daily raw stock returns; ROA, EBITDA scaled by total assets; Jensen, Jensen's productivity measure, measured as the change in market value of the firm less an assumed $8 \%$ return on capital 
expenditures, scaled by market value at the beginning of the period (Jensen, 1993); Returns, annual raw stock returns (Returns model uses contemporaneous explanatory variables). The independent variables are: \%Option Comp (Dir), the value of stock options granted during the year to non-management directors divided by total compensation, except for the Variance of Returns model (Model 3a) where Option Comp is an indicator variable set equal to 1 if the firm granted options to non-management directors during the previous year; \%Inside Directors, percentage of directors who are also employees of the firm; t-statistics are in parentheses. Board Size, the number of directors on the board; CEO Duality, an indicator variable that equals 1 if the board chair and the CEO are the same individuals; \%Ownership(Dir), average percentage of outstanding shares owned by board members; Market-to-book, market value of equity divided by the book value of equity; Firm Size, the natural log of total assets; Leverage, the book value of debt to total assets; Asset Turnover, sales divided by average total assets; Number of Segments, natural log of the number of segments as reported by Compustat; \%Option Comp (CEO), the value of stock options granted during the year to the firm's CEO divided by total compensation.

$*(* *)(* * *)=$ significant at the $0.10,0.05$, and 0.01 levels, respectively. 


\begin{tabular}{|c|c|c|c|}
\hline \multicolumn{4}{|c|}{ Table 6} \\
\hline \multicolumn{4}{|c|}{$\begin{array}{l}\text { Panel A: Ordinary Least Squares Models of the Relation between Director } \\
\text { Option Compensation and Hypothesized Determinants }\end{array}$} \\
\hline Independent Variables & Expected Sign & Estimate & t-statistics \\
\hline RND & $(+)$ & 0.853 & $5.42^{* * *}$ \\
\hline Z-score & $(+)$ & 0.010 & $7.94^{* * *}$ \\
\hline Firm Size & $(+,-)$ & -0.009 & $-1.88^{*}$ \\
\hline Utility & $(-)$ & -0.122 & $-2.52^{* *}$ \\
\hline Leverage & $(-)$ & -0.173 & $-4.83^{* * *}$ \\
\hline Free Cash Flows & $(-)$ & -0.328 & $-3.84^{* * *}$ \\
\hline Marginal Tax Rate & $(-)$ & -0.084 & 1.36 \\
\hline$\%$ Inside & $(+)$ & 0.031 & 0.51 \\
\hline Board Size & $(-)$ & -0.019 & $-8.77^{* * * *}$ \\
\hline CEO Duality & $(-)$ & -0.044 & $-4.35^{* * *}$ \\
\hline$\%>62$ & $(-)$ & -0.096 & $-3.77^{* * *}$ \\
\hline$\%$ Option Comp (CEO) & $(+)$ & 0.161 & $9.39^{* * *}$ \\
\hline \% Stock Comp (CEO) & $(-)$ & -0.050 & $-1.89^{*}$ \\
\hline Pension (Dir) & $(-)$ & -0.052 & $-3.62^{* * *}$ \\
\hline \% Ownership (Dir) & $(-)$ & -0.002 & -1.13 \\
\hline$\%$ Ownership (Inst) & $(+,-)$ & 0.080 & $5.62^{* * *}$ \\
\hline $\operatorname{Adj} R^{2}$ & & 0.224 & \\
\hline
\end{tabular}

The dependent variable is \%Option Comp, measured as the value of non-management director stock options granted during the year (using the Black Scholes model) divided by total non-management compensation; $\boldsymbol{R N D}$ is research and development expense scaled by firm value; Market to Book is market value of equity divided by book value of equity; Leverage is the book value of debt to total assets; Z-score, is Altman's Z-score from Altman (1993); Utility is an indicator variable assigned a value of 1 if the firm is in the utility industry. Firm Size, the natural log of total assets; Free Cash Flows are operating income before depreciation less the sum of income tax, interest and dividends scaled by the firm's market value; Marginal Tax Rate is the firm's simulated marginal tax rate (following Graham, 1996); \%Inside Directors is the percentage of directors who are also employees of the firm; Board Size is the number of directors on the board; $\%>\mathbf{6 2}$ is the percentage of board members older than 62; CEO Duality is an indicator variable assigned a value of 1 if the firm's chair and CEO are the same individual; \%Option Comp (CEO) is the value of stock options granted during the year to the firm's CEO divided by total compensation; \%Stock Comp (CEO) is the value of restricted stock during the year to the firm's CEO divided by total compensation; Pension (Dir) is an indicator variable assigned a value of 1 if the firm has a pension plan for non-management directors; \%Ownership (Inst) is the log of the percentage of shares owned by institutional shareholders; \%Ownership (Dir) is the log of the average percentage of outstanding shares owned by all of the firm's board members; Reported t-statistics are robust to serial correlation and heteroscedasticity.

$*, * *, * * *=$ significant at the $0.10,0.05,0.01$ levels, respectively. 


\begin{tabular}{|c|c|c|c|c|c|c|c|c|}
\hline \multicolumn{9}{|c|}{$\begin{array}{c}\text { Panel B: Two Stage Least Squares Models between Future Firm Characteristics and } \\
\text { Board Stock Option Compensation and Board Characteristics }\end{array}$} \\
\hline Model & 1 & 2 & 3 & $3 a$ & 4 & 5 & 6 & 7 \\
\hline $\begin{array}{l}\text { Independent } \\
\text { Variables } \\
(\text { at period } \mathrm{t})\end{array}$ & $\Delta \mathrm{Rnd}_{\mathrm{t}+1}$ & $\Delta \mathrm{CapEx}_{\mathrm{t}+1}$ & $\begin{array}{l}\text { Variance } \\
\text { Returns }_{\mathrm{t}+1}\end{array}$ & $\begin{array}{l}\text { Variance } \\
\text { Returns }_{\mathrm{t}+1}\end{array}$ & $\mathrm{ROA}_{\mathrm{t}+1}$ & Jensen $_{\mathrm{t}+1}$ & Returns $_{\mathrm{t}}$ & $\begin{array}{c}\text { (Q) } \\
\text { Market-to- } \\
\text { book }_{\mathrm{t}+1} \\
\end{array}$ \\
\hline $\begin{array}{l}\text { \%Option } \\
\text { Comp (Dir) }\end{array}$ & $\begin{array}{r}0.011 \\
(4.95)^{* * *}\end{array}$ & $\begin{array}{c}0.221 \\
(5.09)^{* * *}\end{array}$ & $\begin{array}{c}3 \times 10^{-4} \\
(5.10)^{* *}\end{array}$ & $\begin{array}{c}1 \times 10^{-4} \\
(3.89)^{* *}\end{array}$ & $\begin{array}{c}0.023 \\
(2.72)^{* *}\end{array}$ & $\begin{array}{c}0.164 \\
(5.48)^{* * *}\end{array}$ & $\begin{array}{c}0.111 \\
(3.83)^{* * *}\end{array}$ & $\begin{array}{c}1.130 \\
(3.19)^{* *}\end{array}$ \\
\hline $\begin{array}{l}\text { \% Inside } \\
\text { Director }\end{array}$ & $\begin{array}{c}0.006 \\
(1.12)\end{array}$ & $\begin{array}{c}0.188 \\
(1.83)^{*}\end{array}$ & $\begin{array}{l}2 \times 10^{-4} \\
(1.53)\end{array}$ & $\begin{array}{l}2 \times 10^{-4} \\
(1.60)\end{array}$ & $\begin{array}{c}0.038 \\
(1.88)\end{array}$ & $\begin{array}{c}0.247 \\
(3.37)^{* *}\end{array}$ & $\begin{array}{l}-0.059 \\
(-0.73)\end{array}$ & $\begin{array}{c}0.369 \\
(0.42)\end{array}$ \\
\hline Board Size & $\begin{array}{l}-7 \times 10^{-5} \\
(-0.23)\end{array}$ & $\begin{array}{l}-7 \times 10^{-4} \\
(-0.12)\end{array}$ & $\begin{array}{l}-5 \times 10^{-5} \\
(-6.90)^{* * *}\end{array}$ & $(-8.06)^{* * *}$ & $\begin{array}{l}0.003 \\
(2.46)^{* *}\end{array}$ & & & $\begin{array}{l}0.123 \\
(2.60)^{* *}\end{array}$ \\
\hline CEO Duality & & & $\begin{array}{l}-5 \times 10^{-5} \\
(-1.45) \\
\end{array}$ & $\begin{array}{l}-6 \times 10^{-5} \\
(-1.92)^{*}\end{array}$ & $\begin{array}{c}0.008 \\
(1.65)^{*}\end{array}$ & $\begin{array}{l}-0.010 \\
(-0.60)\end{array}$ & $\begin{array}{l}-0.015 \\
(-0.79)\end{array}$ & \\
\hline $\begin{array}{l}\text { \% Ownership } \\
\text { (Dir) }\end{array}$ & & & $\begin{array}{l}-2 \times 10^{-5} \\
(-2.66)^{* *}\end{array}$ & $\begin{array}{l}-2 \times 10^{-5} \\
(-3.01)^{* *}\end{array}$ & $\begin{array}{l}-1 \times 10^{-5} \\
(-0.01)\end{array}$ & $\begin{array}{l}-8 \times 10^{-4} \\
(-0.22)\end{array}$ & $\begin{array}{c}0.003 \\
(0.97)\end{array}$ & $\begin{array}{c}0.169 \\
(3.85)^{* * *}\end{array}$ \\
\hline $\begin{array}{l}\text { Market-to- } \\
\text { book }\end{array}$ & $\begin{array}{l}7 \times 10^{-5} \\
(1.23)\end{array}$ & $\begin{array}{c}0.002 \\
(1.74)^{*}\end{array}$ & $\begin{array}{l}8 \times 10^{-6} \\
(0.61)\end{array}$ & $\begin{array}{l}1 \times 10^{-6} \\
(1.05)\end{array}$ & $\begin{array}{c}8 \times 10^{-4} \\
(3.57)^{* *}\end{array}$ & $\begin{array}{l}-9 \times 10^{-4} \\
(-1.13)\end{array}$ & $\begin{array}{c}0.003 \\
(2.95)^{* *}\end{array}$ & $\begin{array}{c}0.077 \\
(7.86)^{* * *}\end{array}$ \\
\hline Firm Size & $\begin{array}{l}4 \times 10^{-4} \\
(0.84)\end{array}$ & $\begin{array}{c}0.009 \\
(0.87) \\
\end{array}$ & $\begin{array}{l}-2 \times 10^{-5} \\
(-1.72)^{*}\end{array}$ & $\begin{array}{l}2 \times 10^{-6} \\
(0.14)\end{array}$ & $\begin{array}{l}-0.004 \\
(-2.08)^{* *}\end{array}$ & $\begin{array}{r}0.009 \\
(1.53) \\
\end{array}$ & $\begin{array}{l}-0.009 \\
(-1.45) \\
\end{array}$ & $\begin{array}{c}0.272 \\
(3.17)^{* *}\end{array}$ \\
\hline Leverage & & & $\begin{array}{c}-1 \times 10^{-4} \\
(-1.69)^{*}\end{array}$ & $\begin{array}{l}-2 \times 10^{-4} \\
(-3.43)^{*}\end{array}$ & & & & \\
\hline $\mathrm{ROA}$ & $\begin{array}{c}0.030 \\
(5.44)^{* * *} \\
\end{array}$ & $\begin{array}{l}0.264 \\
(2.47)^{* *}\end{array}$ & & & $\begin{array}{c}0.492 \\
(23.88)^{* * *}\end{array}$ & $\begin{array}{r}0.123 \\
(1.63) \\
\end{array}$ & $\begin{array}{l}0.511 \\
(6.28)^{* * *}\end{array}$ & $\begin{array}{l}5.253 \\
(6.07)^{* * *}\end{array}$ \\
\hline Asset Turnover & & & & & $\begin{array}{c}0.015 \\
(4.64)^{* * *}\end{array}$ & & & \\
\hline $\begin{array}{l}\text { Number } \\
\text { Segments }\end{array}$ & & & & & & & & $\begin{array}{l}-0.428 \\
(-2.90)^{* *}\end{array}$ \\
\hline $\begin{array}{l}\text { \% Option } \\
\text { Comp (CEO) }\end{array}$ & $\begin{array}{c}0.008 \\
(3.72)^{* *}\end{array}$ & $\begin{array}{c}-0.014 \\
(-0.33)\end{array}$ & $\begin{array}{l}3 \times 10^{-4} \\
(5.63)^{* * *}\end{array}$ & $\begin{array}{l}3 \times 10^{-5} \\
(0.81)\end{array}$ & $\begin{array}{l}-0.005 \\
-(0.62)\end{array}$ & $\begin{array}{l}-0.003 \\
(-0.10)\end{array}$ & $\begin{array}{l}-0.089 \\
(-2.87)^{* *}\end{array}$ & $\begin{array}{l}0.912 \\
(2.62)^{* *}\end{array}$ \\
\hline$\Delta \mathrm{Rnd}$ & $\begin{array}{l}7 \times 10^{-4} \\
(0.71)\end{array}$ & & & & & & & $\begin{array}{c}0.458 \\
(3.23)^{* *}\end{array}$ \\
\hline$\Delta$ CapEx & & $\begin{array}{r}0.000 \\
(0.12) \\
\end{array}$ & & & & & & $\begin{array}{c}-0.000 \\
(-0.65) \\
\end{array}$ \\
\hline $\begin{array}{l}\text { Variance of } \\
\text { Returns }\end{array}$ & & & $\begin{array}{c}0.400 \\
(29.16)^{* * *}\end{array}$ & $\begin{array}{c}0.423 \\
(31.47)^{* * *}\end{array}$ & & $\begin{array}{l}-44.607 \\
(-4.65)^{* * *}\end{array}$ & & \\
\hline Jensen & & & & & & $\begin{array}{c}0.000 \\
(0.86)\end{array}$ & & \\
\hline Returns & & & & & & & $\begin{array}{l}-0.010 \\
(-3.62)^{* *}\end{array}$ & \\
\hline Adj. $R^{2}$ & 0.07 & 0.07 & 0.38 & 0.37 & 0.21 & 0.07 & 0.06 & 0.09 \\
\hline
\end{tabular}

The dependent variables are (without subscripts): $\Delta \boldsymbol{R} \boldsymbol{n d}$, change in RND scaled by total assets at the beginning of the period; $\Delta \boldsymbol{C a p E x}$, year to year percentage change in capital expenditures (from the investing section of the Statement of 
Cash flows); Variance of Returns, variance of daily raw stock returns; ROA, EBITDA scaled by total assets; Jensen, Jensen's productivity measure, measured as the change in market value of the firm less an assumed $8 \%$ return on capital expenditures, scaled by market value at the beginning of the period (Jensen, 1993); Returns, annual raw stock returns (Returns model uses contemporaneous explanatory variables). The independent variables are: \%Option Comp (Dir), the value of stock options granted during the year to non-management directors divided by total compensation, except for the Variance of Returns model (Model 3a) where Option Comp is an indicator variable set equal to 1 if the firm granted options to non-management directors during the previous year; \%Inside Directors, percentage of directors who are also employees of the firm; t-statistics are in parentheses. Board Size, the number of directors on the board; CEO Duality, an indicator variable that equals 1 if the board chair and the CEO are the same individuals; \%Ownership(Dir), average percentage of outstanding shares owned by board members; Market-to-book, market value of equity divided by the book value of equity; Firm Size, the natural log of total assets; Leverage, the book value of debt to total assets; Asset Turnover, sales divided by average total assets; Number of Segments, natural log of the number of segments as reported by Compustat; \%Option Comp (CEO), the value of stock options granted during the year to the firm's CEO divided by total compensation.

$*(* *)(* * *)=$ significant at the $0.10,0.05$, and 0.01 levels, respectively. 


\begin{tabular}{|c|c|c|c|c|}
\hline \multicolumn{5}{|c|}{$\begin{array}{c}\text { Table } 7 \\
\text { Tobit Models of the Relation between the Percentage of Director Restricted } \\
\text { Stock Compensation and Hypothesized Determinants }\end{array}$} \\
\hline & \multicolumn{2}{|c|}{ Model 1} & \multicolumn{2}{|c|}{ Model 2} \\
\hline Independent Variables & Estimate & t-statistics & Estimate & t-statistics \\
\hline \multicolumn{5}{|l|}{ Agency Costs } \\
\hline RND & -0.241 & -1.02 & & \\
\hline Market to Book & & & -0.001 & -1.17 \\
\hline Leverage & 0.063 & 1.27 & 0.088 & $1.84^{*}$ \\
\hline Z-score & -0.007 & $-2.80^{* *}$ & -0.004 & $-1.73^{*}$ \\
\hline Utility & -0.005 & -0.20 & 0.001 & 0.06 \\
\hline Firm Size & 0.058 & $9.77^{* * *}$ & 0.060 & $9.98^{* * *}$ \\
\hline \multicolumn{5}{|l|}{ Economic Determinants } \\
\hline Free Cash Flow & 0.054 & 0.38 & 0.075 & 0.54 \\
\hline Marginal Tax Rate & 0.019 & 0.19 & 0.061 & 0.64 \\
\hline \multicolumn{5}{|l|}{ Board Characteristics } \\
\hline$\%$ Inside Directors & -0.494 & $-6.61^{* * *}$ & -0.539 & $-7.28^{* * *}$ \\
\hline Board Size & 0.013 & $3.91^{* * * *}$ & 0.010 & $3.31^{* * *}$ \\
\hline$\%>62$ & -0.253 & $-6.20^{* * *}$ & -0.246 & $-6.07^{* * *}$ \\
\hline CEO Duality & -0.006 & -0.35 & 0.003 & 0.18 \\
\hline \multicolumn{5}{|l|}{ Other Pay and Controls } \\
\hline$\%$ Option Comp (CEO) & 0.027 & 0.96 & 0.032 & 1.17 \\
\hline$\%$ Stock Comp (CEO) & 0.164 & $3.77^{* * *}$ & 0.193 & $4.43^{* * *}$ \\
\hline \% Option Comp (Dir) & -0.866 & $-21.09^{* * *}$ & -0.870 & $-21.69^{* * *}$ \\
\hline Pension (Dir) & -0.081 & $-4.32^{* * *}$ & -0.067 & $-3.63^{* * *}$ \\
\hline$\%$ Ownership (Inst) & 0.095 & $3.52^{* * *}$ & 0.098 & $3.67^{* * * *}$ \\
\hline \% Ownership (Dir) & -0.025 & $-4.43^{* * *}$ & -0.022 & $-4.44^{* * *}$ \\
\hline
\end{tabular}

The dependent variable is \% Stock Comp, measured as the value of non-management stock grants during the year divided by total non-management compensation; $\boldsymbol{R N D}$ is research and development expense scaled by firm value; Market to Book is market value of equity divided by book value of equity; Leverage is the book value of debt to total assets; Z-score, is Altman's Z-score from Altman (1993); Utility is an indicator variable assigned a value of 1 if the firm is in the utility industry. Firm Size, the natural log of total assets; Free Cash Flows are operating income before depreciation less the sum of income tax, interest and dividends scaled by the firm's market value; Marginal Tax Rate is the firm's simulated marginal tax rate (following Graham, 1996); \%Inside Directors is the percentage of directors who are also employees of the firm; Board Size is the number of directors on the board; $\%>62$ is the percentage of board members older than 62; CEO Duality is an indicator variable assigned a value of 1 if the firm's chair and CEO are the same individual; \%Option Comp (CEO) is the value of stock options granted during the year to the firm's CEO divided by total compensation; \%Stock Comp (CEO) is the value of restricted stock during the year to the firm's CEO divided by total compensation; \%Option Comp (Dir) is the value of stock options granted during the year to non-management directors divided by total compensation; Pension (Dir) is an indicator variable assigned a value of 1 if the firm has a pension plan for non-management directors; \%Ownership (Inst) is the log of the percentage of shares owned by institutional shareholders; \%Ownership (Dir) is the log of the average percentage of outstanding shares 
owned by all of the firm's board members; Reported t-statistics are robust to serial correlation and heteroscedasticity. $*, * *, * * *=$ significant at the $0.10,0.05,0.01$ levels, respectively. 


\begin{tabular}{|c|c|c|c|c|c|c|c|}
\hline \multicolumn{8}{|c|}{$\begin{array}{l}\text { Ordinary Least Squares Models between Changes in Future Investments, Future Stock Volatility, } \\
\text { Future and Current Firm Performance and Non-Management Director Restricted Stock } \\
\text { Compensation, Board Characteristics, Director Stock Options, and Other Control Variables }\end{array}$} \\
\hline Model & 1 & 2 & 3 & 4 & 5 & 6 & 7 \\
\hline $\begin{array}{l}\text { Independent } \\
\text { Variables } \\
(\text { at period } \mathrm{t})\end{array}$ & $\Delta \mathrm{Rnd}_{\mathrm{t}+1}$ & $\Delta \operatorname{CapEx}_{\mathrm{t}+1}$ & $\begin{array}{l}\text { Variance } \\
\text { Returns }_{\mathrm{t}+1}\end{array}$ & $\mathrm{ROA}_{\mathrm{t}+1}$ & Jensen $_{t+1}$ & Returns $_{\mathrm{t}}$ & $\begin{array}{l}\text { (Q) } \\
\text { Market-to- } \\
\text { book }_{\mathrm{t}+1}\end{array}$ \\
\hline $\begin{array}{l}\text { \% Stock Comp } \\
\text { (Dir) }\end{array}$ & $\begin{array}{c}-0.003 \\
(-1.34)\end{array}$ & $\begin{array}{l}-0.087 \\
(-1.85)^{*}\end{array}$ & $\begin{array}{l}-2 \times 10^{-4} \\
(-2.62)^{* *}\end{array}$ & $\begin{array}{c}0.002 \\
(0.29)\end{array}$ & $\begin{array}{l}-0.060 \\
(-1.49)\end{array}$ & $\begin{array}{l}-0.011 \\
(-0.30)\end{array}$ & $\begin{array}{c}-0.067 \\
(-0.18)\end{array}$ \\
\hline $\begin{array}{l}\text { \% Inside } \\
\text { Director }\end{array}$ & $\begin{array}{c}0.006 \\
(1.40)\end{array}$ & $\begin{array}{l}0.182 \\
(1.97)^{* *}\end{array}$ & $\begin{array}{l}4 \times 10^{-4} \\
(2.60)^{* *}\end{array}$ & $\begin{array}{c}0.019 \\
(1.11)\end{array}$ & $\begin{array}{c}0.247 \\
(3.02)^{* *}\end{array}$ & $\begin{array}{c}0.008 \\
(0.11)\end{array}$ & $\begin{array}{r}0.431 \\
(0.57)\end{array}$ \\
\hline Board Size & $\begin{array}{l}-3 \times 10^{-4} \\
(-1.31)\end{array}$ & $\begin{array}{c}-0.005 \\
(-0.99)\end{array}$ & $\begin{array}{l}-5 \times 10^{-5} \\
(-5.75)^{* * *}\end{array}$ & $\begin{array}{c}0.001 \\
(1.56)\end{array}$ & & & $\begin{array}{l}0.089 \\
(2.20)^{* *}\end{array}$ \\
\hline CEO Duality & & & $\begin{array}{l}-9 \times 10^{-5} \\
(-2.24)^{* *}\end{array}$ & $\begin{array}{c}0.004 \\
(0.83)\end{array}$ & $\begin{array}{c}0.000 \\
(0.04)\end{array}$ & $\begin{array}{c}-0.003 \\
(-0.19)\end{array}$ & \\
\hline $\begin{array}{l}\text { \% Ownership } \\
\text { (Dir) }\end{array}$ & & & $\begin{array}{l}-2 \times 10^{-5} \\
(-2.13)^{* *}\end{array}$ & $\begin{array}{l}2 \times 10^{-4} \\
(0.18)\end{array}$ & $\begin{array}{c}0.001 \\
(0.25)\end{array}$ & $\begin{array}{c}0.004 \\
(0.92)\end{array}$ & $\begin{array}{c}0.160 \\
(3.90)^{* * *}\end{array}$ \\
\hline $\begin{array}{l}\text { Market-to- } \\
\text { book }\end{array}$ & $\begin{array}{l}9 \times 10^{-5} \\
(1.68)^{*}\end{array}$ & $\begin{array}{c}0.002 \\
(1.85)^{*}\end{array}$ & $\begin{array}{c}0.000 \\
(0.40)\end{array}$ & $\begin{array}{l}7 \times 10^{-4} \\
(3.56)^{* * *}\end{array}$ & $\begin{array}{l}-0.001 \\
(-1.23)\end{array}$ & $\begin{array}{l}0.007 \\
(5.58)^{* * *}\end{array}$ & $\begin{array}{c}0.089 \\
(9.45)^{* * *}\end{array}$ \\
\hline Firm Size & $\begin{array}{l}3 \times 10^{-4} \\
(0.84)\end{array}$ & $\begin{array}{c}0.016 \\
(1.82)^{*}\end{array}$ & $\begin{array}{l}-3 \times 10^{-5} \\
(-1.68)^{*}\end{array}$ & $\begin{array}{l}-0.006 \\
(-3.88)^{* *}\end{array}$ & $\begin{array}{c}0.012 \\
(1.94)^{*}\end{array}$ & $\begin{array}{l}-0.010 \\
(-1.86)^{*}\end{array}$ & $\begin{array}{l}0.195 \\
(2.74)^{* *}\end{array}$ \\
\hline Leverage & & & $\begin{array}{l}-7 \times 10^{-5} \\
(-0.72)\end{array}$ & & & & \\
\hline $\mathrm{ROA}$ & $\begin{array}{l}0.029 \\
(6.36)^{* * *}\end{array}$ & $\begin{array}{l}0.261 \\
(2.64)^{* *}\end{array}$ & & $\begin{array}{c}0.507 \\
(19.07)^{* * *}\end{array}$ & $\begin{array}{l}0.232 \\
(2.79)^{* *}\end{array}$ & $\begin{array}{l}0.142 \\
(3.50)^{* *}\end{array}$ & $\begin{array}{l}5.309 \\
(6.78)^{* * *}\end{array}$ \\
\hline Asset Turnover & & & & $\begin{array}{c}0.014 \\
(5.19)^{* * *}\end{array}$ & & & \\
\hline $\begin{array}{l}\text { Number } \\
\text { Segments }\end{array}$ & & & & & & & $\begin{array}{l}-0.386 \\
(-2.97)^{* *}\end{array}$ \\
\hline $\begin{array}{l}\text { \% Option } \\
\text { Comp (CEO) }\end{array}$ & $\begin{array}{l}0.009 \\
(5.26)^{* * *}\end{array}$ & $\begin{array}{r}0.022 \\
(0.59)\end{array}$ & $\begin{array}{l}4 \times 10^{-4} \\
(6.42)^{* * *}\end{array}$ & $\begin{array}{r}0.007 \\
(1.11)\end{array}$ & $\begin{array}{c}0.056 \\
(1.75)^{*}\end{array}$ & $\begin{array}{l}-0.074 \\
(-2.60)^{* *}\end{array}$ & $\begin{array}{l}1.351 \\
(4.56)^{* *}\end{array}$ \\
\hline$\Delta \mathrm{Rnd}$ & $\begin{array}{l}9 \times 10^{-4} \\
(1.08)\end{array}$ & & & & & & $\begin{array}{c}0.466 \\
(3.53)^{* *}\end{array}$ \\
\hline$\Delta$ CapEx & & $\begin{array}{c}-0.000 \\
(-0.15)\end{array}$ & & & & & $\begin{array}{c}-0.000 \\
(-0.69)\end{array}$ \\
\hline $\begin{array}{l}\text { Variance of } \\
\text { Returns }\end{array}$ & & & $\begin{array}{c}0.451 \\
(26.38)^{* * *}\end{array}$ & & $\begin{array}{c}-10.373 \\
(-1.20)\end{array}$ & & \\
\hline Jensen & & & & & $\begin{array}{r}0.000 \\
(1.02)\end{array}$ & & \\
\hline Returns & & & & & & $\begin{array}{c}-0.003 \\
(-1.47)\end{array}$ & \\
\hline Adj. $\mathrm{R}^{2}$ & 0.04 & 0.06 & 0.28 & 0.24 & 0.06 & 0.03 & 0.08 \\
\hline
\end{tabular}


The dependent variables are (without subscripts): $\Delta \boldsymbol{R} \boldsymbol{n d}$, change in RND scaled by total assets at the beginning of the period; $\Delta \boldsymbol{C a p E x}$, year to year percentage change in capital expenditures (from the investing section of the Statement of Cash flows); Variance of Returns, variance of daily raw stock returns; $\boldsymbol{R} \boldsymbol{O} \boldsymbol{A}$, EBITDA scaled by total assets; Jensen, Jensen's productivity measure, measured as the change in market value of the firm less an assumed $8 \%$ return on capital expenditures, scaled by market value at the beginning of the period (Jensen, 1993); Returns, annual raw stock returns (Returns model uses contemporaneous explanatory variables). The independent variables are: \%Stock Comp (Dir), the value of restricted stock granted during the year to non-management directors divided by total compensation; \%Inside Directors, percentage of directors who are also employees of the firm; tstatistics are in parentheses. Board Size, the number of directors on the board; CEO Duality, an indicator variable that equals 1 if the board chair and the CEO are the same individuals; \%Ownership(Dir), average percentage of outstanding shares owned by board members; Market-tobook, market value of equity divided by the book value of equity; Firm Size, the natural log of total assets; Leverage, the book value of debt to total assets; Asset Turnover, sales divided by average total assets; Number of Segments, natural log of the number of segments as reported by Compustat; \%Option Comp (CEO), the value of stock options granted during the year to the firm's CEO divided by total compensation.

$*(* *)(* * *)=$ significant at the $0.10,0.05$, and 0.01 levels, respectively. 